\title{
Supercritical methane adsorption and storage in pores in shales and isolated kerogens
}

\author{
Thomas F. Rexer ${ }^{1,3} \cdot$ Eliza J. Mathia ${ }^{1,4} \cdot$ Andrew C. Aplin $^{2} \cdot$ K. Mark Thomas ${ }^{1}$ (I)
}

Received: 1 December 2019 / Accepted: 13 March 2020 / Published online: 31 March 2020

(c) The Author(s) 2020 OPEN

\begin{abstract}
Shale gas is an important hydrocarbon resource in a global context. It has had a significant impact on energy resources in the US, but the worldwide development of this methane resource requires further research to increase the understanding of the relationship of shale structural characteristics to methane storage capacity. In this study a range of gas adsorption, microscopic, mercury injection capillary pressure porosimetry and pycnometry techniques were used to characterize the full range of porosity in a series of shales of different thermal maturity. Supercritical methane adsorption methods for shale under conditions which simulate geological conditions (up to $473 \mathrm{~K}$ and $15 \mathrm{MPa}$ ) were developed. These methods were used to measure the methane adsorption isotherms of Posidonia shales where the kerogen maturity ranged from immature, through oil window, to gas window. Subcritical methane and carbon dioxide adsorption studies were used for determining pore structure characteristics of the shales. Mercury injection capillary pressure porosimetry was used to characterize the meso and macro porosity of shales. The sum of the $\mathrm{CO}_{2}$ sorption pore volume at $195 \mathrm{~K}$ and mercury injection capillary pressure pore volumes $(1093-5.6 \mathrm{~nm})$ were equal to the corresponding total pore volume $(<1093 \mathrm{~nm})$ thereby giving an equation accounting for virtually all the available shale porosity. These measurements allowed quantification of all the available porosity in shales and were used for estimating the contributions of methane stored as 'free' compressed gas and as adsorbed gas to overall methane storage capacity of shales. Both the mineral and kerogen components of shale were studied by comparing shale and the corresponding isolated kerogens so that the relative contributions of these components could be assessed. The results show that the methane adsorption characteristics were much higher for the kerogens and represented $35-60 \%$ of the total adsorption capacity for the shales used in this study, which had total organic contents in range 5.8-10.9 wt\%. Microscopy studies revealed that the pore systems in clay-rich, organic-rich and microfossil-rich parts of shale are very different, and also the importance of the inter-granular organic-mineral interface.
\end{abstract}

Keywords Shales $\cdot$ Kerogens $\cdot$ Methane $\cdot$ Adsorption $\cdot$ Mercury porosimetry $\cdot$ Microscopy

This paper was presented for the 2019 Energy \& Fuels Joint Award for Excellence in Publication at the American Chemical Society Meeting 24-29th August 2019 in San Diego, USA.

K. Mark Thomas, mark.thomas@ncl.ac.uk|'Wolfson Northern Carbon Reduction Laboratories, School of Engineering, Newcastle University, Newcastle upon Tyne NE1 7RU, UK. ${ }^{2}$ Science Laboratories, Department of Earth Sciences, Durham University, Durham DH1 3LE, UK. ${ }^{3}$ Present Address: Max Planck Institute for Dynamics of Complex Technical Systems, Magdeburg, Germany. ${ }^{4}$ Present Address: Chemostrat Ltd, Welshpool, Wales, UK. 


\section{Introduction}

The development of shale gas as a methane resource started in the US and it has become an increasingly important component of natural gas supply in the past twenty years [1]. There are large potential shale gas reserves in the rest of the world, which could be exploited in the future. Compared to coal, shale only contains relatively small amounts of methane, but is economic because of very large deposits. The economics of shale gas reservoirs depends on the Gas-in-Place (GIP) and the methane extraction rate that can be achieved [2]. This depends on the properties of the shale and the fracturing of the shale matrix induced by the hydraulic fracking and horizontal drilling processes.

Shales are complex heterogeneous materials comprising of inorganic mineral and organic kerogen components, which leads to wide variations in pore structures and surface chemistry. Methane is stored as either compressed gas or physisorbed gas in porous structures in organic-rich shales and the quantities of these components are very difficult to predict. The gas filled fraction of the porosity follows known relations with pressure and temperature, but it is difficult to predict the quantity. In comparison, the adsorbed gas contribution is poorly understood, but may amount to $50-60 \%$ of the gas in some shales [3]. Shale porous structure characteristics that are particularly relevant for assessing shale reservoir potential are pore volumes, pore size distribution and adsorption characteristics under simulated geological conditions. The economic potential of the resources needs to be established unequivocally, in order to justify extraction of shale gas.

In conventional reservoirs, gas is stored in large pores as 'free', high pressure gas. There is very little gas adsorbed on the walls of macropores compared to free gas in the pores. In contrast, shale is a complex heterogeneous material typically consisting of $>90 \%$ minerals with $<10 \%$ organic kerogen material, in which almost all of the pores are less than a micrometre in diameter. Methane is generated from the decomposition of the organic kerogen phase in shale during geological processes over the temperature range $370-550 \mathrm{~K}$. A gas rich phase is generated at temperatures $>430 \mathrm{~K}$ [4]. Methane is stored in pores, which range from the micropores $(<2 \mathrm{~nm})$, through mesopores $(2-50 \mathrm{~nm})$ to larger macropores, with the adsorbed phase mainly in the micropores in equilibrium with compressed gas in larger meso and macropores through an interconnected pore structure. The adsorbed gas is slow to be released and could be an issue for shale gas exploitation. There have been only a limited number of studies of methane adsorption on shale because of the difficulty in measuring isotherms under supercritical conditions [5-14]. At the outset, measurements were limited to $338 \mathrm{~K}$, but recently these have been extended to higher temperatures $[15,16]$. The amounts of methane in the adsorbed and compressed gas phases need to be quantified in order to understand the delivery mechanism of shale gas to the production well.

The challenge was to quantify the shale porosity, the methane stored in shale as 'free' compressed gas and the adsorbed gas phase, and the relative proportions of methane stored in both the organic and inorganic phases. Since shales contain pore structures ranging from micro to macro pores, a number of techniques must be used to quantify the different pore size ranges. These methods include high pressure supercritical gas adsorption to determine the methane adsorbed phase under simulated geological conditions, mercury injection capillary pressure (MICP) porosimetry for characterizing meso and macro pore characteristics, subcritical gas adsorption for characterizing micro and meso pore structure, helium and grain density measurements to measure the density of pore wall material and microscopy to provide ideas on the origin of kerogen and mineral particle interfaces and pore connectivity. Small-angle neutron scattering techniques may also be used to provide information on shale structure and porosity [17-19].

The porous structures of shales are affected by kerogen maturity [20], mineralogy [21], grain size [22], diagenesis and compaction [23-25]. There have been a number of studies of the relationship between total organic content (TOC) and adsorption characteristics for dry organic rich shales $[5,7,8,14,26]$. Gasparik et al. studied the effect of TOC on methane adsorption capacity for two suites of dry shales with a range of sources and maturity: 1) 6 shales [9] with TOC 1.0-10.5\% did not show a correlation and 2) 28 shales [14] (vitrinite reflectance $\left(V_{R}\right)=0.7-2.4 \%$ ) with TOC (0.4-14.1\%) gave a positive correlation, but with some samples deviating from the trend. Wang et al. found [27] a positive correlation between methane sorption capacity and TOC for 10 Longmaxi shales $\left(V_{R}=2.7-3.68\right.$ and TOC $=1.13-3.59 \%$ ). Liu et al. [28] also investigated 28 Longmaxi shales (TOC $0.25-4.45 \%$ ) and found a positive correlation for methane sorption at 303 and $363 \mathrm{~K}$, with TOC. The complexity of the problem of the relation between methane sorption capacity and TOC over a wide range of shale sources with varying maturities and mineral contents is lack of knowledge of the methane fraction stored in the mineral and organic structures and also, the kerogen structure changes with maturity. An additional factor that needs to be considered is the presence of moisture in shale, which has a detrimental effect on methane sorption $[29,30]$. Clay mineralogy in the shale is an indicator 
of potential for water adsorption [29,31]. The decline in methane sorption capacity with increasing water content has been attributed to competitive adsorption, water cluster formation obstructing access to and occupying pore space. Therefore, methane adsorption capacities for dry shales can be regarded as maximum values whereas moisture equilibrated (relative humidity 97\%) methane sorption capacities can be considered as minimum values [29].

Estimation of organic-rich shale potential for utilization as a gas resource presents major problems and challenges related to the quantification of the amounts of compressed and adsorbed gas and how this is related to shale porous structural characteristics. The aims of the study were:

1. to establish methods for the accurate measurements of supercritical methane adsorption capacity of dry shales at high temperatures and pressures, which simulate geological conditions (up to $15 \mathrm{MPa}$ and $473 \mathrm{~K}$ );

2. to account for all the porosity (micro-, meso- and macro-) in order to estimate the amounts of sorbed gas and 'free' compressed gas stored in shale pores;

3. to determine the relative contributions of the organic kerogen and inorganic mineral phases to overall methane capacity;

4. to establish the role of kerogen content and maturity on methane capacity and

5. to integrate the porous structure characterization data with microscopic data to gain an insight into mineral and kerogen structural interfaces.

\section{Experimental techniques}

\subsection{Shale samples}

The sample of shale Alum 1 was obtained from the Skelbro-2 well in Bornholm, Denmark [32]. The Lower Toarcian Posidonia shales were obtained from the Wickensen (WIC), Harderode (HAR), and Haddessen (HAD) boreholes in Germany (see Fig. 1) [33]. These samples were core samples and the surface showed no significant evidence of contamination. The samples used were taken from the centre of the cores to avoid any possibility of surface contamination. The samples were dried at $105^{\circ}$, but no further treatment of the samples was considered necessary. These sampling and preparation methods were used to ensure that the samples were as far as possible representative of those in the geological formations. Two samples from each borehole were investigated in detail. The maturity of the shale samples increased progressively from the early oil-window Wickensen $\left(V_{R}=0.53 \%\right)$, through the mid oil window Harderode $\left(V_{R}=0.89 \%\right)$, to

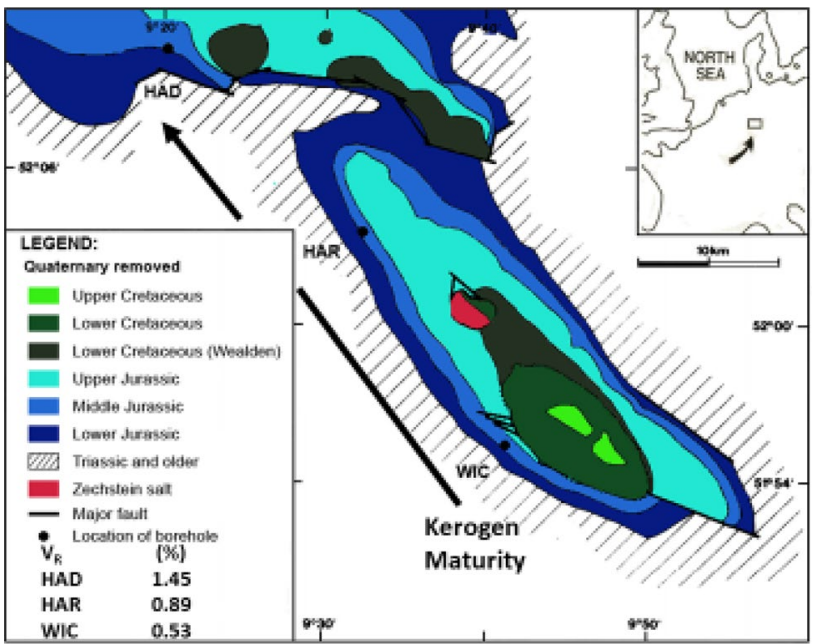

Fig. 1 Posidonia shale samples used in this study (modified from [36])

the gas-window Haddessen $\left(\mathrm{V}_{\mathrm{R}}=1.45 \%\right)$ samples. Characterization data for the samples are given in Tables 1 and 2. The mineralogical compositions of shales in this sample series were similar over the range of maturity with the following ranges: calcite (31-55 wt\%), phyllosilicates (23-37 wt\%), quartz (8-16 wt\%), pyrites (4-9 wt\%), dolomite $(0.3-6.4 \%)$, feldspars (1-5 wt\%). TOC values were in the range $5.8-10.92 \mathrm{wt} \%$ [34]. The shale and kerogen sample set allowed the impact of kerogen maturity on shale and kerogen pore structure on methane capacity to be studied independently of TOC and mineral composition variables.

\subsection{Kerogen samples}

The kerogen samples were separated from the shales. Initially the shales were treated with $\mathrm{HCl}$ to dissolve carbonates and then treated with acidified $\mathrm{CrCl}_{2}$ to remove pyrite. Silicates from this sample were removed by treatment with HF [34]. Kerogen purity was checked by powder X-ray diffraction [34].

\subsection{Density measurements}

\subsubsection{Grain density}

Samples (particle size range: $500-1180 \mu \mathrm{m}$ ) were pre-dried overnight at $105^{\circ} \mathrm{C}$ in air. The sample was weighed in a pre-weighed pycnometer $(50 \mathrm{~mL}) .10 \mathrm{~mL}$ of Teepol soap solution (concentration: $5 \%$ ) was added to the pycnometer, which was then filled with degassed water and left overnight to equilibrate. The pycnometer + sample + water was weighed at $25^{\circ} \mathrm{C}$. The pycnometer was filled with 
Table 1 Well depth, TOC, grain and helium densities, mercury injection pore volumes and total porosities for Alum shale and Posidonia shales and kerogens $[34,35]$

\begin{tabular}{|c|c|c|c|c|c|c|c|c|c|}
\hline Well & Shale sample & Depth (m) & TOC (wt\%) & $\begin{array}{l}\text { Shale grain } \\
\text { density } \\
\left(\mathrm{g} \mathrm{cm}^{-3}\right)\end{array}$ & $\begin{array}{l}\text { Shale density } \\
\text { (helium } \\
\text { pycnometry) } \\
\left(\mathrm{g} \mathrm{cm}^{-3}\right)\end{array}$ & $\begin{array}{l}\text { Shale bulk } \\
\text { vol. (MICP) } \\
\left(\mathrm{cm}^{3} \mathrm{~g}^{-1}\right)\end{array}$ & $\begin{array}{l}\text { shale total } \\
\text { pore vol. } \\
(\%)\end{array}$ & $\begin{array}{l}\text { Kerogen } \\
\text { TOC }^{+} \\
(w t \%)\end{array}$ & $\begin{array}{l}\text { Kerogen } \\
\text { density (helium } \\
\text { pycnometry) } \\
\left(\mathrm{g} \mathrm{cm}^{-3}\right)\end{array}$ \\
\hline \multicolumn{10}{|l|}{ Posidonia } \\
\hline WIC & 7145 & 47.4 & 10.92 & 2.331 & 2.321 & 0.497 & 13.8 & 73 & 1.217 \\
\hline WIC & 7155 & 57.8 & 9.67 & 2.361 & 2.297 & 0.484 & 12.5 & 73 & 1.235 \\
\hline HAR & 7038 & 44.5 & 7.91 & 2.493 & 2.468 & 0.414 & 3.1 & 97 & 1.168 \\
\hline HAR & 7060 & 66.8 & 5.78 & 2.592 & 2.550 & 0.404 & 4.5 & $>99$ & 1.024 \\
\hline HAD & 7090 & 40.1 & 7.41 & 2.572 & 2.556 & 0.439 & 11.4 & 83 & 1.342 \\
\hline HAD & 7119 & 60.6 & 7.15 & 2.607 & 2.614 & 0.445 & 13.7 & 79 & 1.368 \\
\hline \multicolumn{10}{|l|}{ Alum } \\
\hline Skelbro-2 & Alum 1 & 9.4 & 6.35 & 2.592 & & n.a. & n.a. & n.a. & n.a. \\
\hline
\end{tabular}

n.a. not available

${ }^{\dagger}$ The kerogen TOC content is corrected for the residual pyrite content, which could not be removed by the separation process

Table 2 Mineral composition of Posidonia and alum shales in wt $\%$

\begin{tabular}{|c|c|c|c|c|c|c|c|c|c|c|c|}
\hline & Quartz & Plagioclase & Calcite & Dolomite & Pyrite & Gypsum & Muscovite & Illite + I-S & Kaolinite & Chlorite & Other \\
\hline \multicolumn{12}{|c|}{ Posidonia shales } \\
\hline WIC7145 & 13.2 & 1.0 & 46.6 & 0.3 & 3.9 & 2.2 & 0.0 & 22.4 & 5.1 & 2.0 & 3.3 \\
\hline WIC7155 & 8.6 & 1.4 & 55.3 & 0.6 & 5.4 & 2.4 & 0.1 & 19.4 & 2.2 & 1.8 & 2.8 \\
\hline HAR7038 & 15.8 & 2.1 & 43.5 & 0.7 & 5.6 & 0.0 & 3.2 & 18.5 & 8.9 & 0.0 & 1.7 \\
\hline HAR7060 & 13.0 & 2.8 & 30.5 & 6.4 & 9.1 & 0.0 & 3.7 & 26.2 & 6.6 & 0.0 & 1.7 \\
\hline HAD7090 & 16.0 & 3.0 & 39.7 & 1.8 & 5.0 & 1.8 & 1.3 & 23.9 & 3.9 & 0.7 & 2.9 \\
\hline HAD7119 & 8.2 & 4.9 & 49.9 & 2.7 & 4.5 & 3.8 & 0.0 & 19.5 & 1.1 & 2.7 & 2.7 \\
\hline \multicolumn{12}{|l|}{ Alum shale } \\
\hline Alum 1 & 44.4 & 1.0 & 0.5 & & 1.4 & & 9.5 & 35.8 & 0.7 & 4.2 & 2.5 \\
\hline
\end{tabular}

Other minerals includes Feldspar, Siderite, Anatase, Marcasite, Aragonite and Dickite [34, 35]

de-gassed water and weighed at $25^{\circ} \mathrm{C}$ to determine the volume of the pycnometer. The particle grain density was calculated from the above weights and the known density of water at $25^{\circ} \mathrm{C}$.

\subsubsection{Helium density}

Helium density measurements were carried out as part of the high pressure adsorption measurements since the information is necessary for calculating the surface excess values. Pre-dried kerogen and shale samples were loaded into a Hiden Isochema Intelligent Manometric Instrument (IMI). The samples were outgassed typically for $\sim 4 \mathrm{~h}$ ), at $<10^{-4} \mathrm{~Pa}$, at $110^{\circ} \mathrm{C}$ in the IMI instrument before helium pycnometry. Helium dosing at a pressure of $2 \mathrm{MPa}$ at $40^{\circ} \mathrm{C}$ from a reference cell was used with successive evacuation and helium dosing cycles with the skeletal volume and sample density being determined each time. The mean of 3 repeats was used. A stainless steel cylinder was used as a volume calibration standard under matching conditions. The volume of gas injected into the sample cell was calculated using the NIST Standard Reference database 23 by using the REFPROP Version 9.0 software [37]. Helium density measurements were repeatable to $\pm 0.01 \mathrm{~g} \mathrm{~cm}^{-3}$.

\subsection{Adsorption studies}

\subsubsection{Low-pressure adsorption}

An Intelligent Gravimetric Analyzer (IGA), supplied by Hiden Isochema Ltd., Warrington, UK; was used for low temperature nitrogen, carbon dioxide and methane adsorption studies of shales and kerogens. Samples of shales (500-1180 $\mu \mathrm{m})$ and kerogens were out-gassed under ultra-high vacuum at $383 \mathrm{~K}$ until constant weight. Liquid nitrogen (77 K) and solid carbon dioxide/acetone cryogenic baths ( $195 \mathrm{~K}$ ) were used for temperature control. Methane adsorption measurements at $112 \mathrm{~K}$ were 
achieved using a Hiden Isochema cryostat system cooled by gaseous nitrogen generated from liquid nitrogen. A computer controlled recirculating bath of water/ethylene glycol was used for adsorption measurements at $273 \mathrm{~K}$.

Isotherm repeatabilities were typically $\pm 1.5 \%$ for $\mathrm{CO}_{2}$ adsorption at both 196 and $273 \mathrm{~K}$ at $100 \mathrm{kPa}$ and $\pm 1.1 \%$ for $\mathrm{N}_{2}$ uptakes at $77 \mathrm{~K}$ and $99 \mathrm{kPa}$.

\subsubsection{High-pressure supercritical methane sorption}

A Hiden Isochema Intelligent Manometric Instrument (IMI) was used for high pressure $\mathrm{CH}_{4}$ adsorption. Shales and kerogen samples were pre-dried at $383 \mathrm{~K}$ in a vacuum oven and loaded typically with $\sim 10 \mathrm{~g}$ shale (particle size range: $500-1180 \mu \mathrm{m}$ ), $0.8-1.3 \mathrm{~g}$ kerogen (particle size range as produced from demineralization process) into the IMI sample cell. Displacers were employed to reduce the void volume, because only relatively small quantities of kerogen samples were available. The skeletal volumes of the samples were determined, which also allowed calculation of the corresponding helium densities. Methane isotherms were measured at 318,338 and $358 \mathrm{~K}$. Isotherm experimental repeatabilities were typically $\pm 5.0 \%$ for both shale and kerogens at $10 \mathrm{MPa}$. Helium isotherms were measured at all temperatures as blank determinations for no adsorption to monitor skeletal densities and leak-test the instrument.

Saturated vapor pressures $\left(\mathrm{p}_{0}\right)$ and gas densities were calculated from the NIST Standard Reference database 23 by using the REFPROP Version 9.0 software [37]. The following equations of state (EOS) were used: $\mathrm{CO}_{2}$ (Span et al.) [38], $\mathrm{N}_{2}$ (Span et al.) [39], $\mathrm{CH}_{4}$ (Setzmann et al.) [40] and helium (Lemmon et al.) [37].

\subsection{Mercury injection capillary pressure (MICP) porosimetry}

A Micromeritics Autopore IV Mercury Injection Porosimeter was used in the study [34]. MICP could only be used for the shales since kerogens only occur as very small particles in shale. Also, kerogens are plastic and deform under the very high pressures used in the technique. Initially shale samples were freeze-dried for $48 \mathrm{~h}$. Samples with a volume of $\sim 1 \mathrm{~cm}^{-3}$ were then outgassed under vacuum prior to MICP porosimetry studies. The mercury pressure was increased stepwise from 1.379 up to $268.9 \mathrm{MPa}$ in order to characterize the meso/macroporosity. MICP bulk volumes/densities of shale were calculated from the known sample mass and the grain or helium density of the sample. The difference of the volume of mercury injected at 1.379 MPa and 268.9 MPa was used to calculate MICP pore volumes. Surface topography and micro fractures related to the de-stressing and drying of geological samples were excluded (see Table 1). The Washburn equation [41, 42] is derived for cylindrical pores and calculations were carried out assuming a contact angle $141^{\circ}$ between mercury and the particle surface, and a surface tension of $0.485 \mathrm{~N} \mathrm{~m}^{-1}$ $[24,43,44]$. The mercury pressures were used to predict pore throats (constrictions) with equivalent diameters between $1093 \mathrm{~nm}$ at $1.379 \mathrm{MPa}$ and $5.6 \mathrm{~nm}$ at $268.9 \mathrm{MPa}$. These diameters should be regarded as equivalent pore diameters because of the variation in pore shape in the heterogeneous shale materials.

\subsection{Microscopy studies}

Scanning electron microscopy (SEM) was carried out using a Hitachi SU-70 High Resolution Analytical instrument equipped with an Oxford Instrument Energy Dispersive X-ray (EDX) microanalysis system (INCA Energy 700). Samples were prepared as carbon-coated polished thin sections. Back Scattered Electron (BSE) mode used a YAG detector. Some samples ( $3 \mathrm{~mm}$ diameter) were polished with an argon broad ion beam (BIB) in a GATAN 691 Precision lon Polishing System (PIPS ${ }^{\mathrm{TM}}$ ) to reduce shale topography. Secondary Electron (SE) images were obtained using a through-the-lens detector (TLD) at magnifications of up to $10,000 \times$. EDX analysis was used to generate elemental and phase distributions of selected areas.

\section{Results and discussion}

\subsection{Supercritical methane adsorption on shale}

Initially it was necessary to provide information on supercritical methane adsorption characteristics under simulated geological conditions in order to gain an insight into the variation of sorption capacity with temperature and pressure.

\subsubsection{Isotherms}

At the start of the study it was apparent that the accuracy of supercritical gas adsorption measurements at high pressures was not established. Subsequently, an investigation of the accuracy of high pressure supercritical $\mathrm{CO}_{2}$ adsorption measurements on highly porous activated carbons was reported [45]. Similar studies have been reported recently for $\mathrm{CO}_{2}$ adsorption on zeolite ZSM-5 [46]. Initial validation of isotherm reproducibility successfully used a small sample $(\sim 500 \mathrm{mg})$ of F400 activated carbon. The development and validation of high pressure adsorption techniques for measuring supercritical adsorption isotherms for shales is much more challenging than for activated carbon since the adsorption is two orders of 


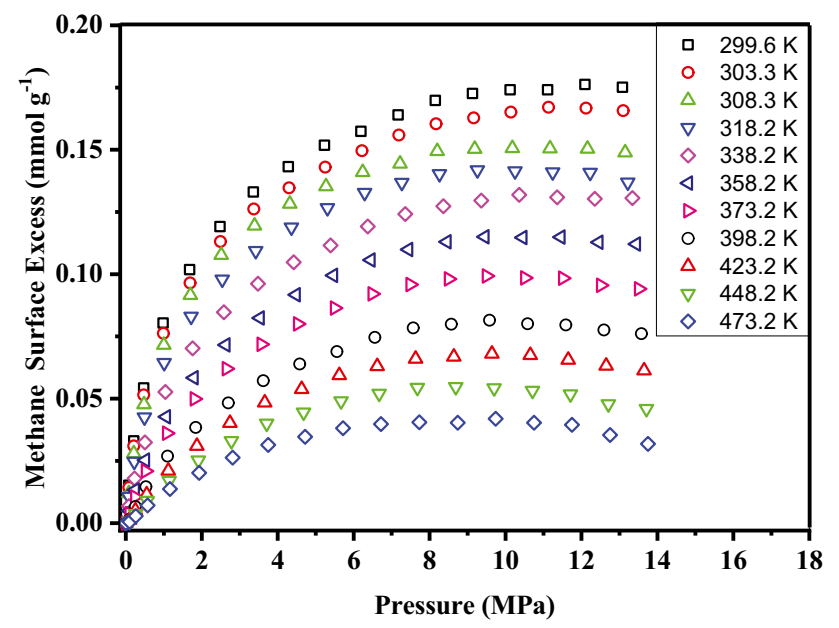

Fig. 2 Supercritical methane adsorption isotherms for Alum 1 shale for temperatures in the range 299.6-473.2 K (data from [35])

magnitude lower. This led to the use of larger sample amounts (typically $10 \mathrm{~g}$ of shale and $\sim 1 \mathrm{~g}$ of kerogen) being used to obtain the required accuracy. These techniques were used to investigate the variation of isotherms under a range of simulated geological pressure and temperature conditions and validate the consistency of the data. Figure 2 shows methane adsorption isotherms for shale Alum 1 over the temperature range $299.6-473.2 \mathrm{~K}$ and pressures up to $\sim 140$ bar [35]. These conditions cover the temperature and pressure range that simulate geological conditions. The reproducibility of the measurements were confirmed in a 'round robin' study of an immature Posidonia shale and an over-mature Upper Chokier formation shale [47]. The Newcastle results were in the middle of the set of results confirming reasonable agreement.

The surface excess isotherm can be converted to the isotherm for the absolute amount using the equation below

$n_{a b s}=n_{e x}+\rho_{b} * V_{a d}$

where $n_{a b s}$ is the absolute amount adsorbed, $n_{e x}$ is the surface excess determined experimentally, $\rho_{b}$ is the bulk gas phase density and $V_{a d}$ is the adsorption pore volume. This equation has been used for crystalline materials, where the structure has been determined from crystallographic studies [48-51]. There is good agreement between crystallographic and adsorption pore volumes. However, shales are heterogeneous materials with a wide pore size distribution and not all larger pores have significant gas adsorption. The issue for shales is to identify the pore size ranges and volumes associated with both adsorption and high pressure compressed gas, which are the phases in equilibrium for methane storage in shale.
3.1.1.1 Isosteric enthalpy of adsorption The isotherm data were used to calculate the isosteric enthalpy of adsorption using the Clausius-Clapeyron equation and to validate the consistency of the data [35]. The derivation of this equation assumes that the gas is ideal and the adsorbed phase volume is neglected. These two assumptions may lead to errors at high pressures [52], which can be examined using graphs $\ln$ (Fugacity) versus $1 / T$ at various surface coverages for the set of data shown in Fig. 3. The linearity of the graphs demonstrate the consistency of the data over simulated geological conditions.

The determination of isosteric enthalpy of adsorption $\left(Q_{s t}\right)$ graph is limited by the availability of data at constant surface coverage. The Clausius-Clapeyron graph for the lowest 5 temperatures and 2.85-7.62 MPa and $\sim 70 \%$ of maximum surface excess $\left(0.125 \mathrm{mmol} \mathrm{g}^{-1}\right)$ gives $Q_{s t}$ of $20.5 \pm 1.3 \mathrm{~kJ} \mathrm{~mol}^{-1}$. This compares with a $Q_{s t}$ of $19.0 \pm 0.2 \mathrm{~kJ} \mathrm{~mol}^{-1}$ for a surface excess of $0.01 \mathrm{mmol} \mathrm{g}^{-1}$. Graphs of $\ln$ (Pressure) versus 1/T gave very similar values for $Q_{s t}$. These values are typical for adsorption of $\mathrm{CH}_{4}$ on shales [8], activated carbon [53-55], coal [56] and metal organic framework materials [57]. There is no evidence for any significant variation in isosteric enthalpy of adsorption even though shale is heterogeneous with a variety of inorganic mineral and organic kerogen components.

\subsubsection{Isobars}

The variation of $\mathrm{CH}_{4}$ surface excess with temperature at constant pressure is important in assessing shale adsorption characteristics under simulated geological conditions. The adsorption isotherm data in Fig. 2 provides information from which the dependence of surface excess

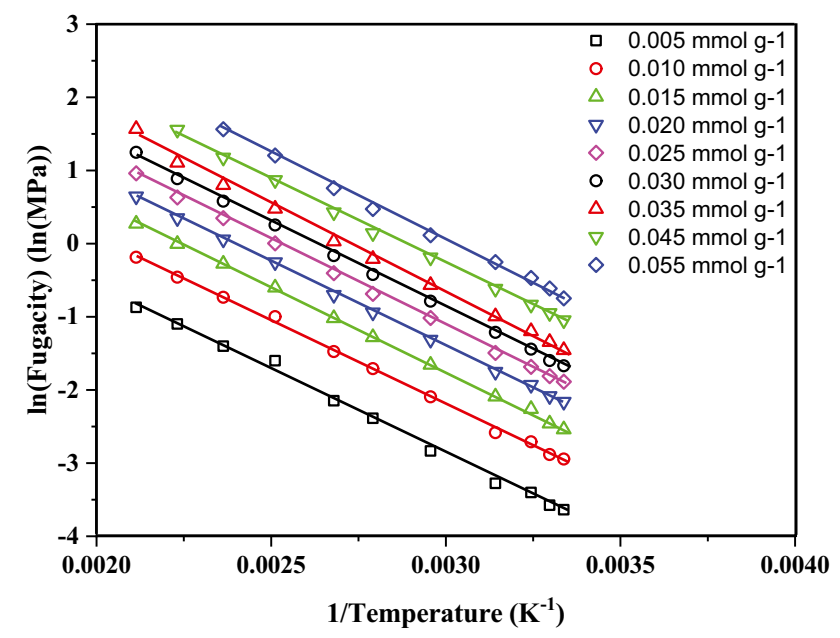

Fig. 3 Clausius-Clapeyron graphs of In(Fugacity) versus 1/temperature for the supercritical adsorption of methane on Alum 1 shale (data from Ref. [35]) 
adsorption on temperature can be determined. Figure 4 shows a comparison of surface excess (SE) isobars for a phenomenological model [SE $=k / T$ where $k$ is a constant and $T$ is temperature $(\mathrm{K})$ ] and the equation proposed by Illin (SE $=k_{1} \exp \left(-k_{2} T^{0.5}\right)$ ) where $k_{1}$ and $k_{2}$ are constants and $T$ is the temperature $(\mathrm{K})[58,59]$. Comparison of the model over the pressure range $0.5-13.5 \mathrm{MPa}$ shows that both equations fit the data, but the simple phenomenological model provides the slightly better fit to the data. Previous studies of supercritical methane adsorption on a metal organic framework have shown that these isobar equations provide good descriptions of the data [57].

\subsubsection{Subcritical $\mathrm{CH}_{4}$ adsorption studies}

Since physisorption increases with decreasing temperature, assessment of the maximum amount of methane that can be adsorbed on a shale was obtained using low temperature subcritical adsorption isotherm. A comparison of the subcritical isotherms for nitrogen, methane and
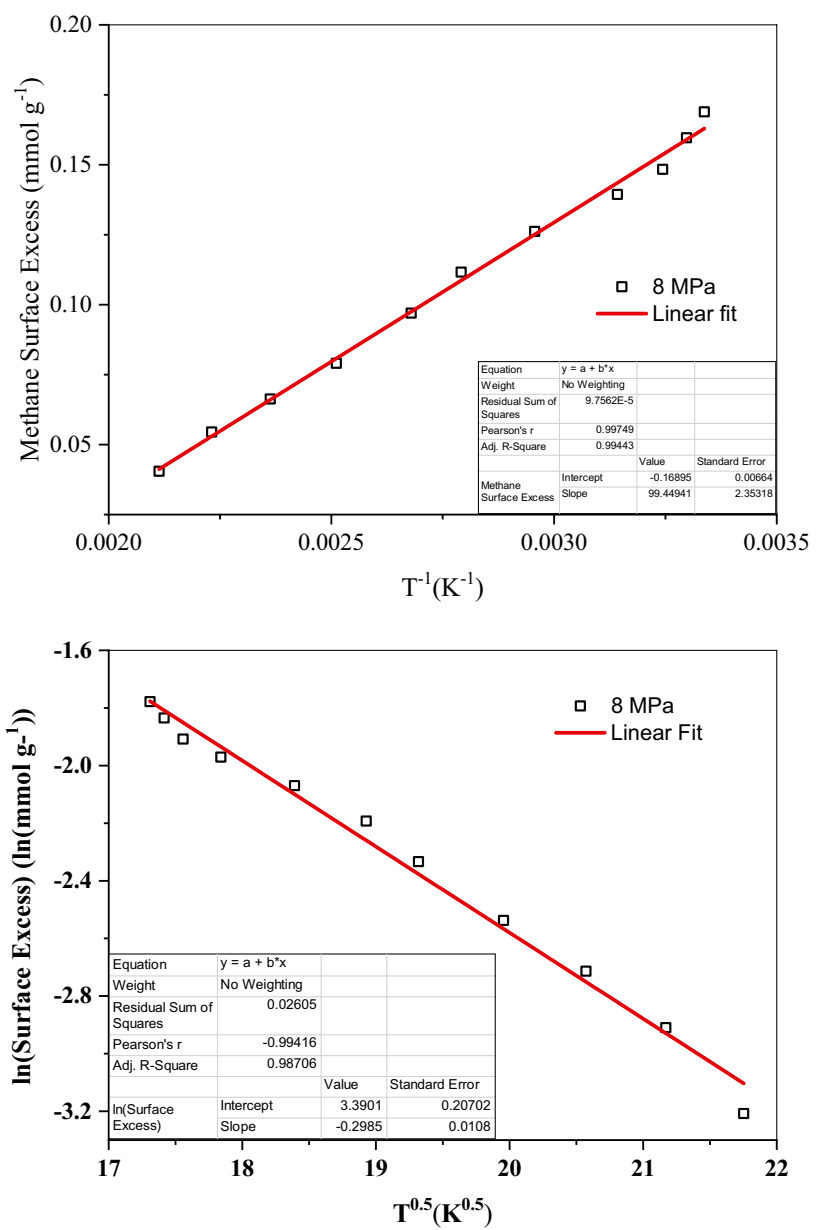

Fig. 4 Isobars for supercritical $\mathrm{CH}_{4}$ adsorption on Alum 1 shale a phenomenological model [35] and $\mathbf{b}$ Illin equation [58] carbon dioxide on a relative pressure basis for the Alum 1 shale are shown in Fig. 5 . The total sorption pore volume obtained from subcritical $\mathrm{CH}_{4}$ adsorption at $112 \mathrm{~K}$ represents the maximum pore volume available for methane adsorption since the low temperature allows measurements with a relative pressure close to 1 , where condensation occurs. There is an experimental difficulty in measuring subcritical $\mathrm{CH}_{4}$ adsorption because of the lack of a suitable cryogenic fluid. The measurement was carried out using a special cell with circulation of cooled gaseous nitrogen, but this is experimentally challenging. The Dubinin-Radushkevich (DR) ultramicropore volume obtained for the Alum 1 shale from $\mathrm{CO}_{2}$ adsorption at $273 \mathrm{~K}$ was $12.9 \mathrm{~mm}^{3} \mathrm{~g}^{-1}$. The sorption pore volumes for subcritical $\mathrm{CO}_{2}$ at $195 \mathrm{~K}\left(16.8 \mathrm{~mm}^{3} \mathrm{~g}^{-1}\right)$ and $\mathrm{CH}_{4}$ at $112 \mathrm{~K}$ $\left(18.0 \mathrm{~mm}^{3} \mathrm{~g}^{-1}\right)$ are similar as expected from the Gurvitch Rule [60]. This rule states that the adsorption uptakes at relative pressure $\approx 1$ on a given adsorbent when expressed as a volume of liquid, using the liquid density, are similar for all adsorptives. Therefore, the $\mathrm{CO}_{2}$ sorption pore volume was used as a substitute for the $\mathrm{CH}_{4}$ total pore volume in subsequent studies of shale maturity, since it is much easier to use solid $\mathrm{CO}_{2}$ /acetone as the cryogenic liquid $[34,35]$. Therefore, when studying the effect of shale and kerogen maturity on supercritical methane adsorption, correlations between subcritical $\mathrm{CO}_{2}$ sorption pore volume and high pressure supercritical methane adsorption were examined to validate this approach.

\subsection{Porosity characterization}

Porosity characterization methods are well developed with the exception of the measurements of supercritical methane adsorption capacities for shales and kerogens

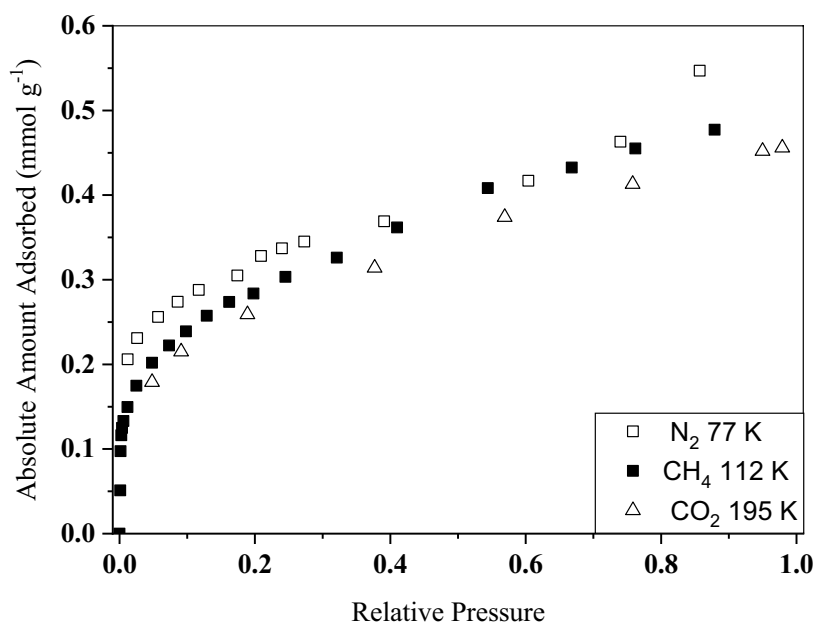

Fig. 5 Subcritical adsorption isotherms for $\mathrm{CH}_{4}(112 \mathrm{~K}), \mathrm{N}_{2}(77 \mathrm{~K})$ and $\mathrm{CO}_{2}(195 \mathrm{~K})$ for Alum 1 shale [35] 
under a range of conditions, which simulate geological conditions of high pressure and temperature. The methane adsorbed phase is expected to be almost exclusively stored in the smallest pores of shales and kerogens. The porosity in which compressed gas is stored in equilibrium with the adsorbed phase mainly involves the larger pores. The strategy for the characterization of shale porosity was to quantify all the porosity from macro- through mesoto micropores to complement the supercritical methane adsorption studies. A range of microscopy, gas adsorption, mercury injection and pycnometry techniques were used in order to explore the full pore size range in shales so that the relative amounts of adsorbed and compressed $\mathrm{CH}_{4}$ could be established. Small-angle neutron scattering techniques may also be used to characterize shale structure and porosity [17-19] but these techniques were not available for this study. The measurements techniques available and size ranges covered are shown in Fig. 6.

Mercury injection capillary pressure (MICP) porosimetry is an established technique for assessing porosity in minerals and it was important in providing measurements of macro and meso $(>5 \mathrm{~nm})$ porosity in shales. MICP porosimetry measures pore throats (smaller passages or constrictions in the pore structure), which are connections between larger pore bodies. The pore throats are obvious restrictions in the pore structure and are typically a fraction of the pore size. The Washburn equation [42] was used to calculate the equivalent pore diameters for mercury entering pores at specific pressures $[24,41,43,44]$. At a pressure of 1.379 MPa mercury enters pores of $>1093 \mathrm{~nm}$ diameter and this allows the shale bulk density $\left(\rho_{\text {HgBulk }}\right)$ to be determined. Therefore $1 / \rho_{\text {HgBulk }}$ is the volume of shale and pores $<1093 \mathrm{~nm}$. Helium is not adsorbed to any significant extent under ambient conditions and enters all accessible pores. Therefore, the volume of shale is $1 / \rho_{\mathrm{He}^{\prime}}$ where $\rho_{H e}$ is the helium density measured by pycnometry

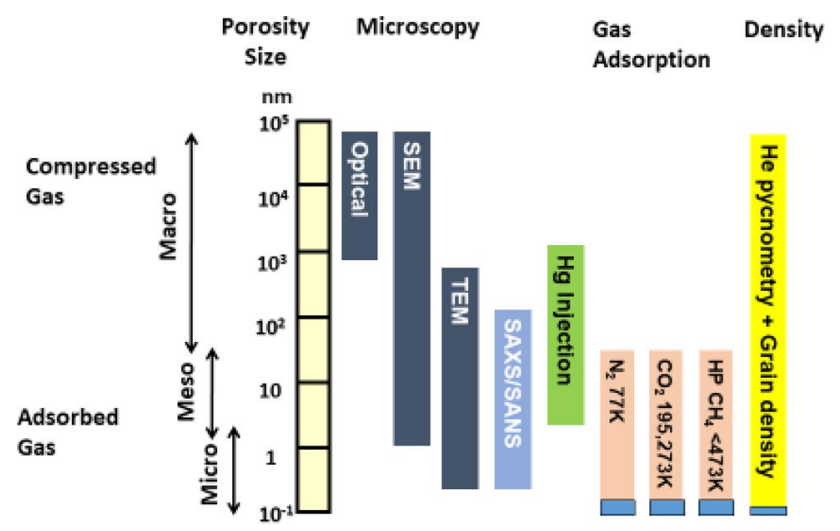

Fig. 6 Measurement techniques and size ranges for characterization of porosity
[34]. As expected grain density and helium density have a strong linear correlation and therefore $\rho_{\text {Grain }}$ can be used in place of $\rho_{\mathrm{He}}$. Therefore, the shale total pore volume (TPV) for equivalent pore diameters $<1093 \mathrm{~nm}$ and Total Porosity are given by the equations below

Total pore volume $(<1093 \mathrm{~nm})=\frac{1}{\rho_{\text {HgBulk }}}-\frac{1}{\rho_{\text {He }}}$

Total porosity $(<1093 \mathrm{~nm})=1-\frac{\rho_{\text {HgBulk }}}{\rho_{\text {He }}}$

The Washburn equation indicates that a capillary pressure of $1.379 \mathrm{MPa}$ fills pore throats up to $1093 \mathrm{~nm}$ and 268.9 MPa fills up to $5.6 \mathrm{~nm}$. Therefore, the MICP pore volume provides a measure of the macro + mesopore volume between equivalent pore diameters of 1093 and $5.6 \mathrm{~nm}$ from the amounts injected at pressure of 1.379 and $268.9 \mathrm{MPa}$.

Subcritical gas adsorption studies are routinely used for characterizing micro and mesoporous structures of porous materials using a variety of isotherm equations [61]. Adsorption occurs in micropores $(<2 \mathrm{~nm})$ and some mesopores ( $>2 \mathrm{~nm}$ ). The Brunauer Emmett and Teller (BET) equation [62] accounts for multilayer adsorption and is usually applied to $\mathrm{N}_{2}$ adsorption isotherm data at $77 \mathrm{~K} . \mathrm{N}_{2}$ adsorption isotherm data at $77 \mathrm{~K}$ has also been used to determine pore size distributions in order to gain insights into organic matter in coal and shales [63,64]. However, characterization parameters such as surface areas, obtained from $\mathrm{N}_{2}$ adsorption at $77 \mathrm{~K}$ may have issues due to activated diffusion effects in ultramicroporous materials at very low temperatures [65-67] and may overestimate surface areas in microporous materials. In this case $\mathrm{CO}_{2}$ adsorption is commonly used to characterize activated carbons $[61,68]$ because of the higher adsorption temperature. $\mathrm{CO}_{2}$ adsorption on shale is also of interest in relation to storage of $\mathrm{CO}_{2}$ in depleted shales for sequestration applications [64]. The Dubinin-Radushkevich (DR) equation [69] is often applied to $\mathrm{CO}_{2}$ isotherms at $273 \mathrm{~K}$ to determine the ultramicropore volumes $(<0.7 \mathrm{~nm})$ [70-72]. Adsorption at $195 \mathrm{~K}$ was used to provide total $\mathrm{CO}_{2}$ sorption pore volumes. Nitrogen adsorption at $77 \mathrm{~K}$ is used to provide BET surface areas and DR micropore volumes (0.3-2 nm) [72].

These techniques were used to characterize the porous structure in shales and kerogens (see Fig. 7) [34]. The $\mathrm{CO}_{2}$ sorption pore volumes were obtained from adsorption isotherms at $195 \mathrm{~K}$. Ultramicropore volumes were obtained using the Dubinin-Radushkevich equation from $\mathrm{CO}_{2}$ adsorption at $273 \mathrm{~K}$. The relationships of these parameters with supercritical methane adsorption is important in the context of accounting for all porosity present in shales by providing pore volumes in relation to pore size for shales. 
Fig. 7 Pore characterization using adsorption based methodologies

\section{Pore characterization using subcritical gas adsorption}

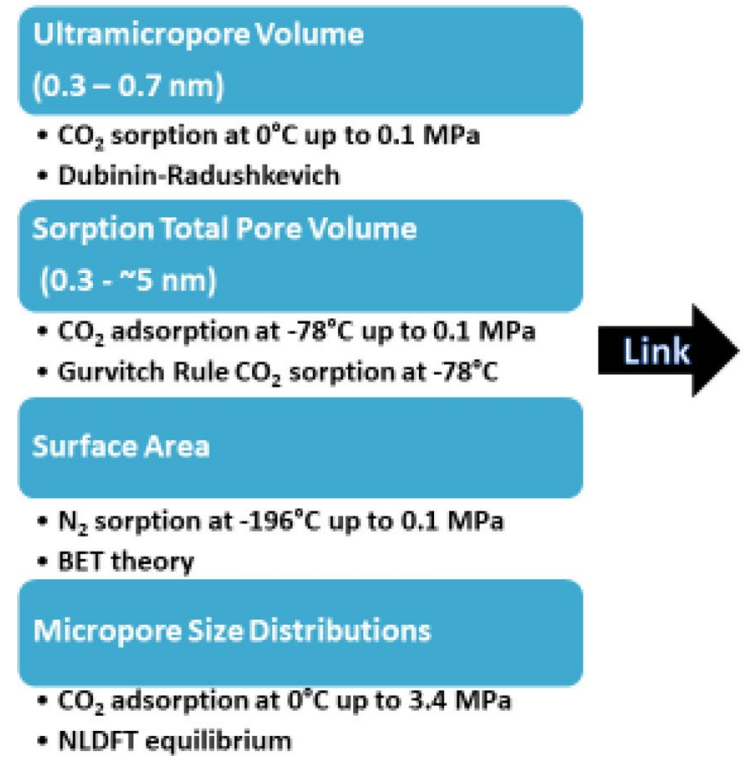

\section{Supercritical gas adsorption} capacity measurements

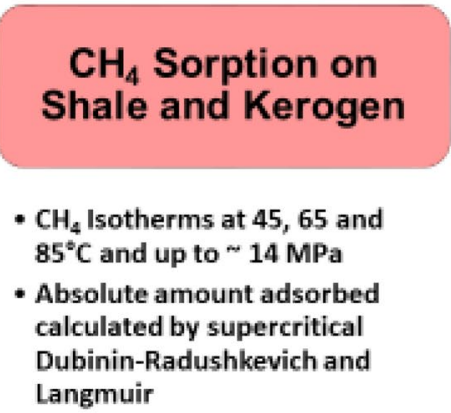

Since shales are heterogeneous materials, microscopic methods were used to visualize macro and meso porosity in order to understand the storage of methane in pores and flow properties of gases through pores. Microscopic methods showed that the suite of Posidonia shale samples did not have significant amounts of porosity above $\sim 1 \mu \mathrm{m}$ in diameter.

\subsection{The role of shale structure and kerogen maturity}

Supercritical $\mathrm{CH}_{4}$ isotherms for Posidonia shales and the corresponding isolated kerogens at $338 \mathrm{~K}$ are shown in Fig. 8 [34]. The isotherms have a Type I shape in the IUPAC Classification scheme [73]. The adsorption isotherms for shales show that the surface excess goes through a minimum for the Harderode (oil window) shales. The adsorption isotherms are similar for Wickensen (immature) and Haddessen (gas window) shales. Similar trends were observed [34] for adsorption on shales at 318 and $358 \mathrm{~K}$.

The supercritical $\mathrm{CH}_{4}$ isotherms for isolated kerogens show different trends (See Fig. 8b). The Haddessen (gas window) kerogens have higher surface excess uptakes than the Wickensen (immature) shales. The Harderode and Wickensen kerogens have similar surface excess isotherms. A similar trend was observed for the adsorption isotherms for isolated kerogens at $338 \mathrm{~K}$. Comparison of the $\mathrm{CO}_{2}$ adsorption isotherms at $195 \mathrm{~K}$ for the suite of shales and kerogens show that they have similar trends for the differences in the order of individual Wickensen, Harderode and Haddessen shales and kerogens as shown for supercritical methane adsorption described above. The $\mathrm{CO}_{2}$ sorption pore volumes for kerogens $\left(71.8-113 \mathrm{~mm}^{3} \mathrm{~g}^{-1}\right)$ are $\times 5-8$ those of shales $\left(8.3-16.4 \mathrm{~mm}^{3} \mathrm{~g}^{-1}\right)$. Thus the trends for shales and kerogens are confirmed. The high pressure shale and kerogen $\mathrm{CH}_{4}$ isotherms can be parameterized and modelled using Langmuir and modified Langmuir equations [34, 35].

It is apparent from comparison of the isotherms of shales and isolated kerogens that the kerogens adsorb 5-8 times more methane than the corresponding shales. The surface excess uptakes of methane on the Posidonia suite of shales at $338 \mathrm{~K}$ were in the range $0.056-0.110 \mathrm{mmol} \mathrm{g}^{-1}$ (40-78 scf t ${ }^{-1}$ ) while the corresponding range for isolated kerogens was $0.36-0.7 \mathrm{mmol} \mathrm{g}^{-1}$ (253-499 $\left.\mathrm{scf} \mathrm{t}^{-1}\right)$ [34]. The isosteric enthalpies of adsorption $\left(Q_{s t}\right)$ for dry Posidonia shales and kerogens were calculated by two methods [74, 75] and were in the range 11.2-15.7 $\mathrm{kJ} \mathrm{mol}^{-1}$ for shales and 8.5-17.2 kJ mol${ }^{-1}$ for kerogens [34]. The $Q_{\text {st }}$ values for $\mathrm{CH}_{4}$ adsorption on alum 1 shale for surface excess values in the range $0.01-0.125 \mathrm{mmol} \mathrm{g}^{-1}$ were $19-20.5 \mathrm{~kJ} \mathrm{~mol}^{-1}$. Ji et al. reported that pre-gas window shales had $Q_{s t}$ values in the range $7.3-15.3 \mathrm{~kJ} \mathrm{~mol}^{-1}$ and a gas window shale was $18.4 \mathrm{~kJ} \mathrm{~mol}^{-1}$ [8]. These $Q_{s t}$ values are similar to previously published values for carbon (9-24 kJ mol${ }^{-1}$ ) [53-55], coal (10-22 kJ mol $\left.{ }^{-1}\right)$ [56] and shale (7-24 kJ mol-1) [8, 76-78].

Comparison of low temperature subcritical $\mathrm{CH}_{4}$ and $\mathrm{CO}_{2}$ adsorption studies at $112 \mathrm{~K}$ and $195 \mathrm{~K}$ at relative pressure $=1$ showed the sorption pore volumes for both gases were very similar in agreement with Gurvitch's rule [35]. This represents the methane maximum sorption volume, which includes micropores $(<2 \mathrm{~nm})$ and some mesopores. 


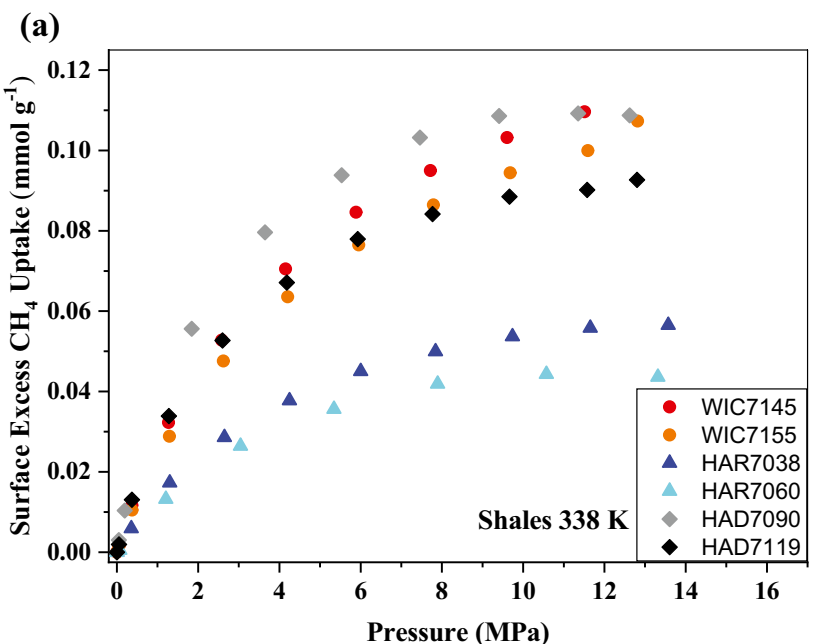

(b)

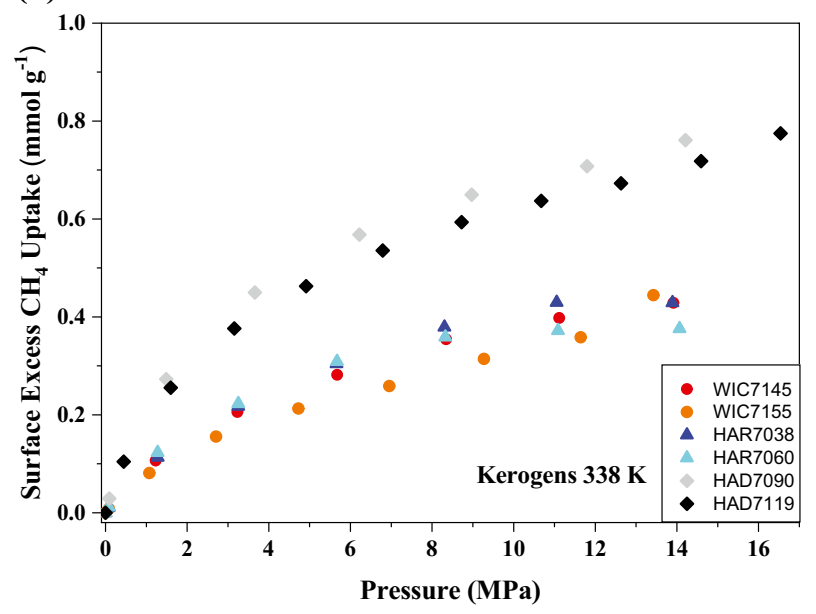

Fig. 8 Supercritical $\mathrm{CH}_{4}$ adsorption isotherms at $338 \mathrm{~K}$ for a shales and $\mathbf{b}$ isolated kerogens (data from [34])

Figure 9 shows the variation of $\mathrm{CH}_{4}$ surface excess at $11.5 \mathrm{MPa}$ and $338 \mathrm{~K}$ with $\mathrm{CO}_{2}$ sorption pore volume for both Posidonia shales and kerogens [34]. The correlation for shales alone had a regression coefficient $\left(R^{2}\right)$ of 0.96 whereas there was more scatter for the kerogens with a $R^{2}$ value of $0.76 \mathrm{It}$ is evident that there is a good overall linear correlation $\left(R^{2}=0.956\right)$ for the combined shale and kerogen data showing the linear relationship passing through the origin between supercritical methane adsorption and $\mathrm{CO}_{2}$ sorption pore volume [34]. Similar correlations were observed for $\mathrm{CH}_{4}$ supercritical adsorption on shales and kerogens at $318 \mathrm{~K}$. This observation supports the use of $\mathrm{CO}_{2}$ sorption pore volume in the assessment of porosity available for high pressure $\mathrm{CH}_{4}$ adsorption to account for the full range of shale porosity in order to assess the storage of compressed and adsorbed gas.

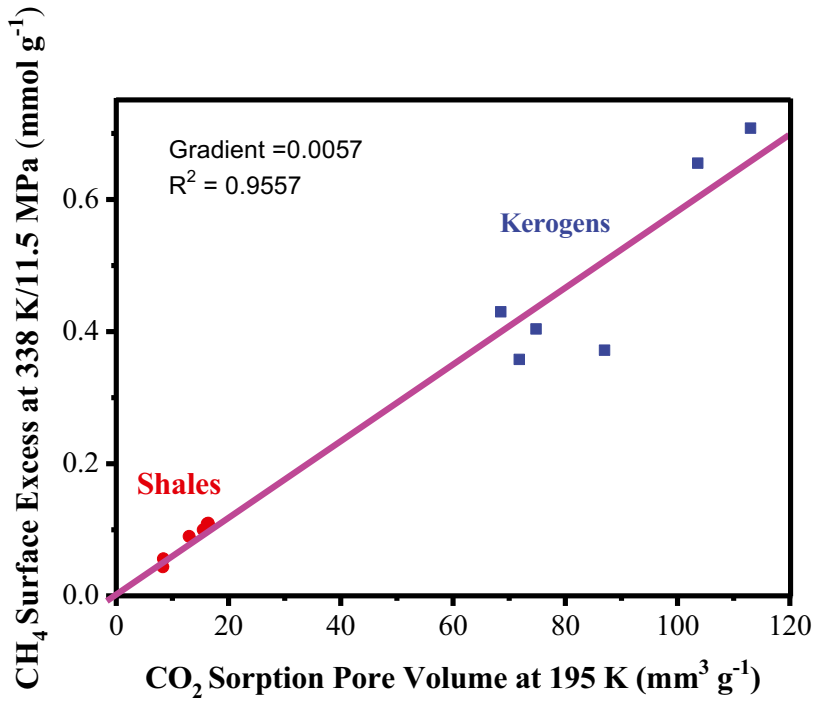

Fig. 9 The variation of high pressure supercritical $\mathrm{CH}_{4}$ surface excess adsorption at $11.5 \mathrm{MPa}$ and $338 \mathrm{~K}$ for Posidonia shales and kerogens with subcritical $\mathrm{CO}_{2}$ sorption pore volume [34]

The interrelations between high-pressure $\mathrm{CH}_{4}$ sorption capacity, maturity, and pore structure characteristics were investigated for shales and isolated kerogens. Mercury injection capillary pressure (MICP) porosimetry measurements could only be studied for larger particle sizes, which are only available for shales. Kerogens only occur as very small particles distributed throughout shales.

Microscopy studies showed that the shales only have sub-micrometre pores. The maximum pore throat size in the shale samples were also determined from MICP. The Washburn equation [42] provides the equivalent pore diameters as a function of injection pressures. The values for maximum pore throat size in the shales pass through a minimum ( $21 \mathrm{~nm}$ for HAR7038 and $24 \mathrm{~nm}$ for HAR7060) for the oil window shales. The largest maximum pore throat size was $547 \mathrm{~nm}$ in gas-window shale HAD7199. The maximum pore throat sizes for WIC7145, WIC7155 and HAD7090 were all very similar $(\sim 156 \mathrm{~nm})$ [34]. The results show that the MICP range $(<1093 \mathrm{~nm})$ studied covers the upper macropore range in this suite of Posidonia shale samples.

Figure 10 shows the variation of Total Pore Volume $(<1093 \mathrm{~nm})$ versus the sum of the $\mathrm{CO}_{2}$ Sorption Pore Volume and MICP pore volume $(5.6-1093 \mathrm{~nm})$. It is apparent that there is a linear relationship $\left(R^{2}=0.99\right)$ intersecting the origin, thereby accounting for all the porosity in the shales. This relationship allows predictions of the volumes available for adsorbed and compressed methane and hence stored amounts of adsorbed and compressed gas using an estimated density for the adsorbed phase and known equations of state for the gas phase. 


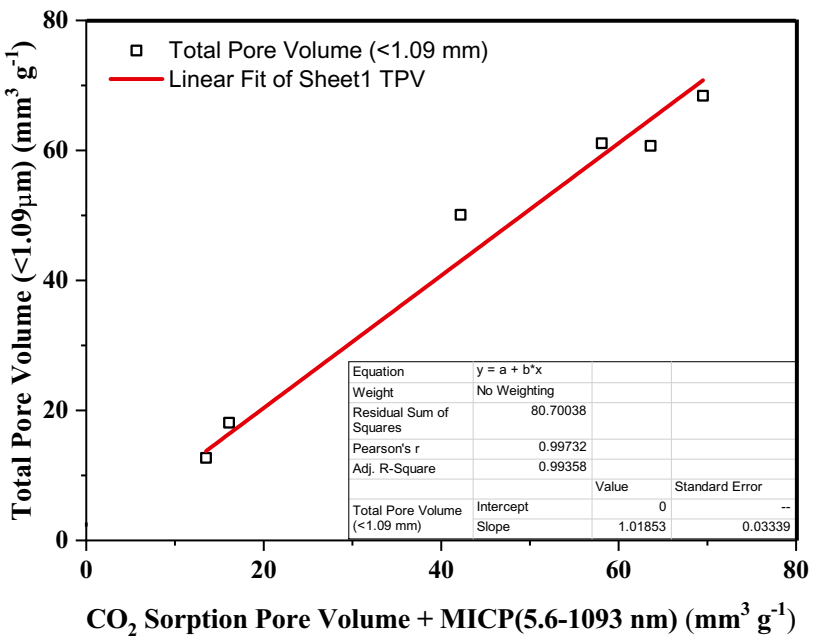

Fig. 10 The variation of shale total pore volume with the sum of $\mathrm{CO}_{2}$ sorption pore volume and MICP pore volume [34]

Total pore volume $(<1093 \mathrm{~m})$

$$
\begin{aligned}
= & \mathrm{CO}_{2} \text { sorption pore volume } \\
& + \text { MICP pore volume }(5.6-1093 \mathrm{~nm})
\end{aligned}
$$

The DR micropore, $\mathrm{CO}_{2}$ sorption and MICP porosimetry total pore volumes for shales pass through a minimum in the oil window. Wickensen (immature) shales have $\mathrm{CO}_{2}$ sorption pore volumes that are $\sim 25 \%$ of the total pore volume. $\mathrm{HAR}$ (oil window) shales have $\mathrm{CO}_{2}$ sorption pore volumes that are $46-66 \%$ of total pore volume and there is less porosity present as larger pores. This is due to compaction and bitumen filling. HAD (gas window) shales have $\mathrm{CO}_{2}$ sorption pore volume that are $21-32 \%$ of total pore volume. The $\mathrm{DRCO}_{2}$ micropore volumes as a percentage of the $\mathrm{CO}_{2}$ sorption pore volume were $41-62 \%$ and $40-52 \%$ for the shales and kerogens, respectively. This suggests that there is ultramicroporosity in the mineral component of shale as well as the kerogen. In comparison, the DR micropore volumes of coals are in the range $0.014-0.052 \mathrm{~cm}^{3} \mathrm{~g}^{-1}$ [79-81]. The trend observed for $\mathrm{CO}_{2}$ DR micropore volume with coal maturity has a minimum for medium volatile bituminous coals. This is ascribed pore filling by low volatile hydrocarbon species followed by decomposition during coalification [82].

Figure 11 shows the variation of DR micropore volume, $\mathrm{CO}_{2}$ sorption pore volume and $\mathrm{Hg}$ total pore volume with vitrinite reflectance for Posidonia shales and Fig. 12 shows the corresponding variation of DR micropore volume and $\mathrm{CO}_{2}$ sorption pore volume for isolated kerogens. Comparison of Figs. 11 and 12 shows that the minimum in $\mathrm{CO}_{2}$ sorption pore volume observed for the oil window shales is not observed for the corresponding kerogens indicating the significant contribution of porosity in the mineral phase of the shale. The clay content of the Posidonia shales

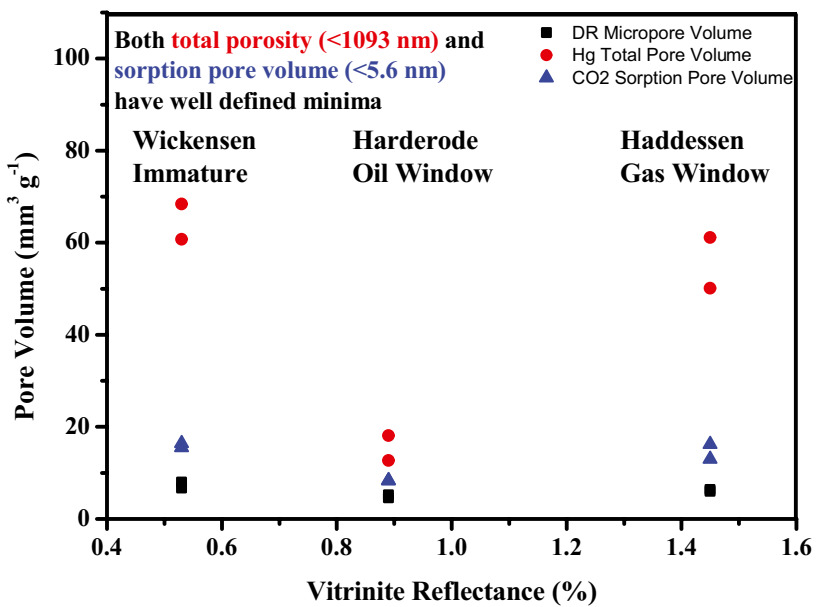

Fig. 11 The variation of Dubinin-Radushkevich micropore volume, $\mathrm{CO}_{2}$ sorption pore volume $(<\sim 5.6 \mathrm{~nm})$ and $\mathrm{Hg}$ total pore volume from MICP porosimetry at $1093 \mathrm{~nm}$ with vitrinite reflectance for Posidonia shales (data from Ref. [34])

is relatively small with illite/smectite and kaolinite in the range $18.5-26.2 \mathrm{wt} \%$ and $1.1-8.9 \mathrm{wt} \%$, respectively. These clays adsorb $\mathrm{CH}_{4}$ and are present in dry shales $[76,83]$. Since the kerogens adsorb 5-8 times more $\mathrm{CH}_{4}$ than dry Posidonia shales, a correlation with TOC with some scatter associated with differences in maturity and mineral content would be expected (Fig. 12). Clays are present in the Posidonia shales and dry clays adsorb methane [76, 83]. The isotherms observed for shale, clay content and kerogen and the composition of the shales do not always account for all the adsorbed $\mathrm{CH}_{4}$. This suggests that some porosity occurs in other mineral components and possibly occurs between organic and mineral matter interfaces [34]. This observation and the different trends for the series

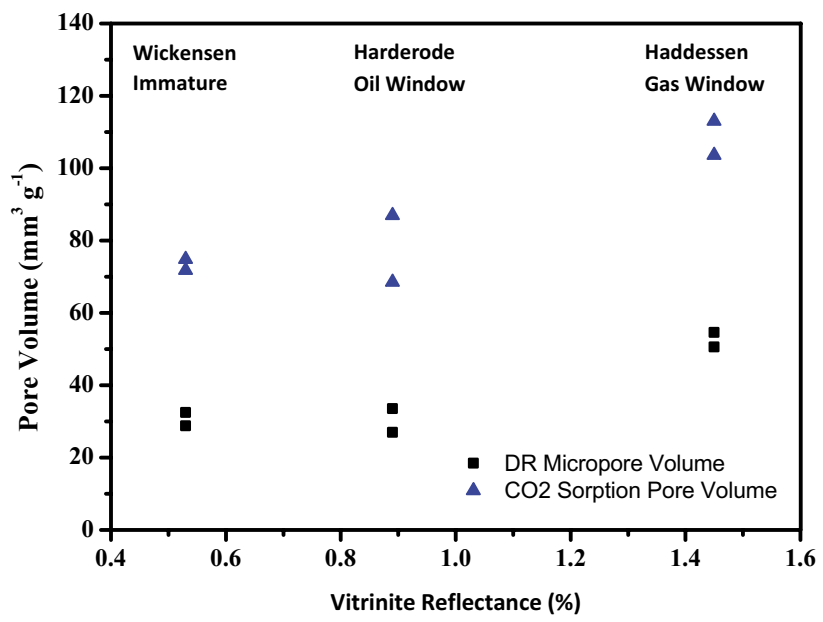

Fig. 12 The variation $\mathrm{CO}_{2}$ sorption pore volumes and DR micropore volumes with vitrinite reflectance for isolated kerogens derived from Posidonia shales 


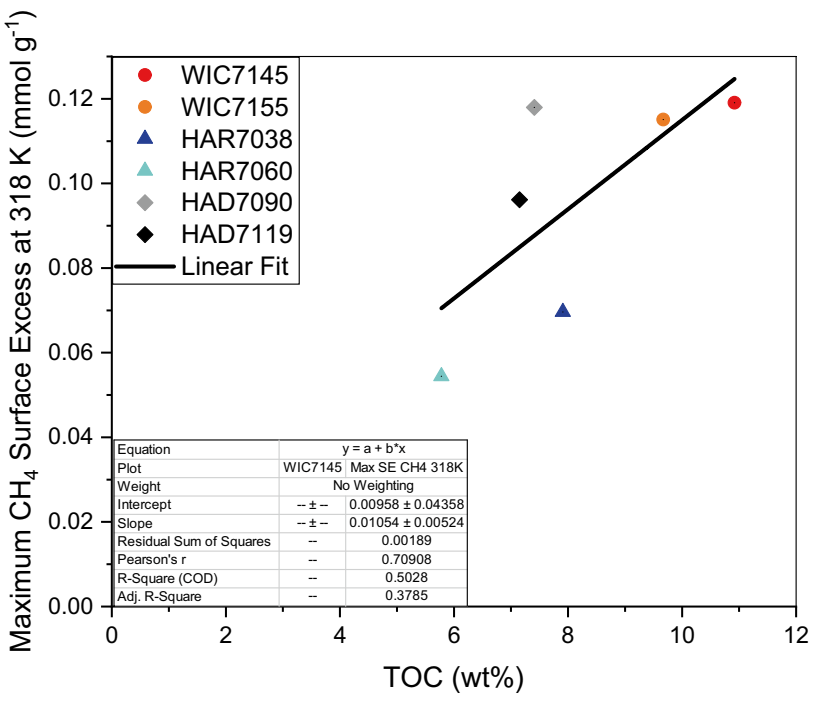

Fig. 13 The variation of maximum $\mathrm{CH}_{4}$ surface excess uptake at $318 \mathrm{~K}$ with TOC [34]

of shales and kerogen adsorption isotherms in Fig. 8, may explain the relatively large scatter in the points in the linear correlation between maximum shale capacity at $318 \mathrm{~K}$ and TOC shown in Fig. 13.

Porosity distribution between the mineral and kerogen phases is important in the context of identifying correlations between methane storage and geochemical characterization data. Taking into consideration the TOC, 30-60\% of the shale sorption pore volume is due to adsorption in the kerogen even though in these shales the TOC is $5.8-10.9 \%$ of the shale (see Fig. 14a) [34]. Since the $\mathrm{CO}_{2}$ sorption pore volume has a linear correlation with supercritical $\mathrm{CH}_{4}$ adsorption (Fig. 9) and the correlation in Eq. (4), the shale pore volume $(5.6-1093 \mathrm{~nm})$ determined using MICP porosimetry contains almost exclusively compressed gas which should be easily accessible. Figure $14 \mathrm{~b}$ shows a typical comparison of supercritical shale adsorption of methane normalized to TOC with the kerogen methane isotherm [34]. These isotherms have a very similar shape suggesting that the kerogen in the shale has similar adsorption characteristics to the isolated kerogen indicating that the kerogen extraction process had little or no effect on the kerogen adsorption characteristics. Comparisons for other Posidonia shales and kerogens show the same similarity in isotherm shapes. This suggests that the kerogen adsorption properties are unchanged by the extraction/isolation process and implies that adsorption also takes place in the inorganic mineral phase. This is not surprising since clays are present. Some differences might also arise from accessibility within the rock matrix, but there is no direct evidence to support this proposition.
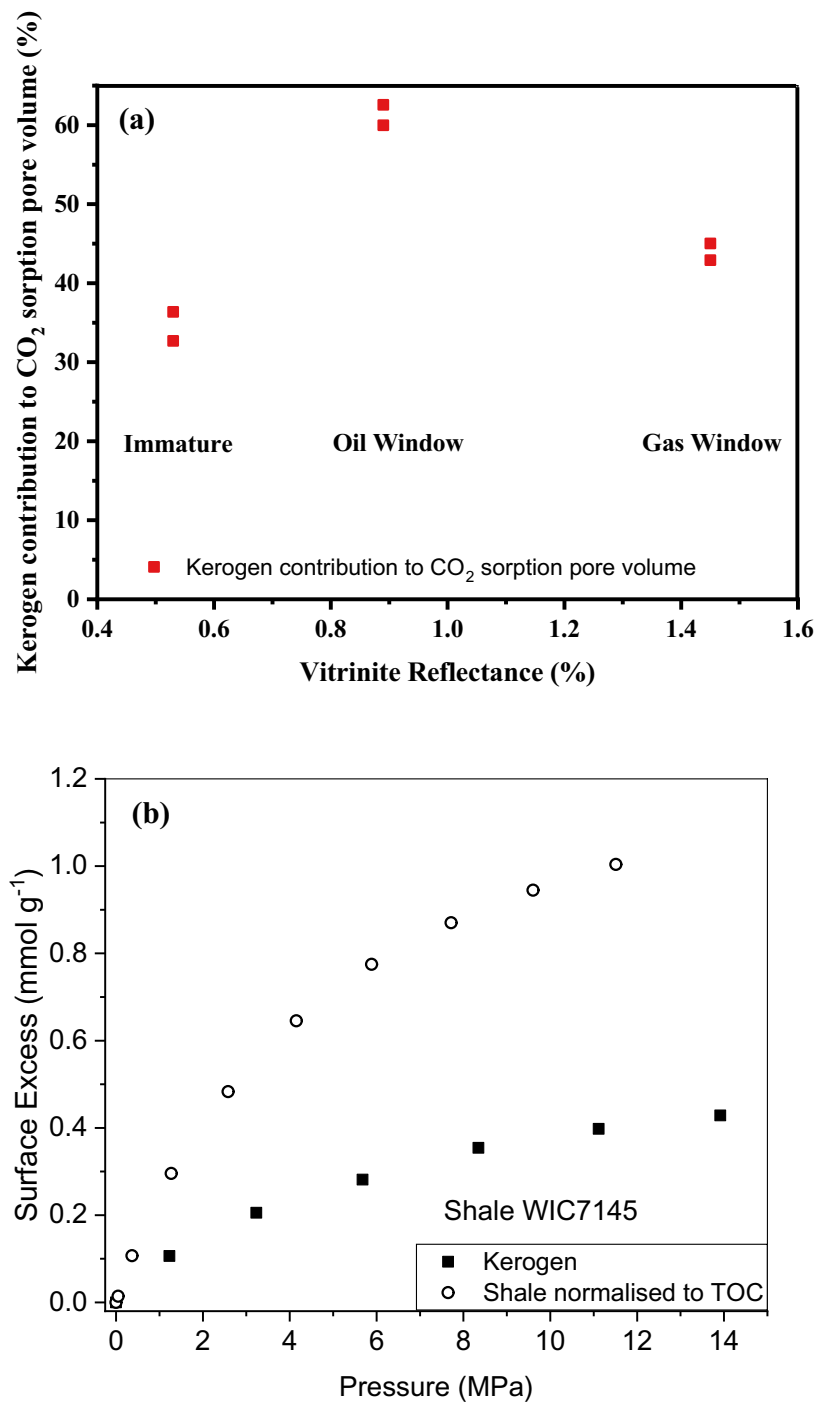

Fig. 14 Kerogen contributions to Posidonia shale adsorption a $\mathrm{CO}_{2}$ sorption pore volumes ( $195 \mathrm{~K}$ ), b comparison of supercritical $\mathrm{CH}_{4}$ adsorption isotherms at $338 \mathrm{~K}$ for shale normalized to TOC with the isolated immature kerogen WIC7145

The research has been extended further to examine the microporous region by microscopic visualization and quantification of pores, which is significant in understanding the sorbed gas versus compressed gas capacity as well as the flow properties. Microscopy was used to study a wider range of 26 Posidonia shales [36]. Typical micrographs are shown in Fig. 15. In the case of immature shales, pores quantifiable by SEM (>ca. $50 \mathrm{~nm}$ diameter) only account for small part of total porosity. Visible pores are mainly associated with biogenic calcite. There was essentially no macroporosity in the clay matrix or kerogen components. Porosity loss in the oil window shales is due to a) compaction, b) carbonate cementation and possible swelling of kerogen by retained oil. In the gas window shales, porosity 


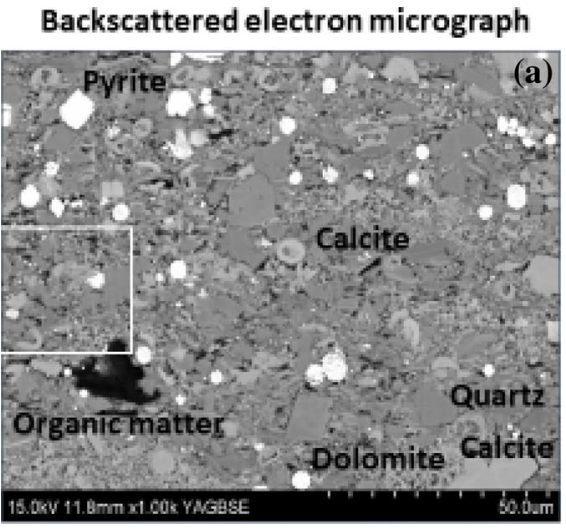

Fig. 15 Micrographs of HAR 7060 shale (oil window): [36, 84]. a Back scattered electron micrographs calcareous shale with densely packed nanofossil aggregates. Partial recrystallization of the nanofossil rich shale matrix and presence of calcite and dolomite

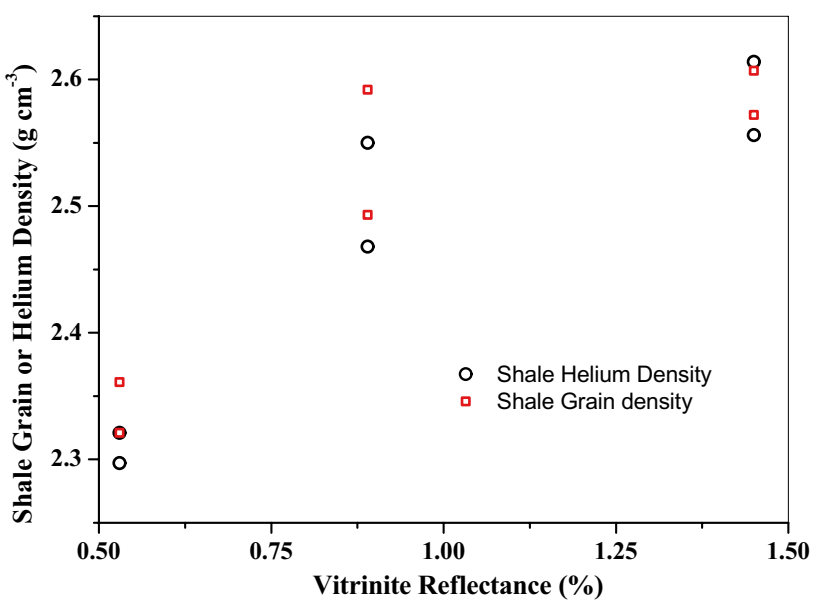

Fig. 16 The variation of helium and grain densities for shales for Posidonia shales with vitrinite reflectance (data from Ref. [34])

increases due to the formation of meso and macro pores in organic matter related to thermal cracking and gas generation. The macroporosity varies greatly and this reflects the different physicochemical characteristics of individual organic phase particles and the surrounding rigid mineral matrix preventing compaction of the more ductile organic phases. Helium and grain densities have a linear relationship and increase with increasing maturity for shales (see Fig. 16) [34]. The development of organic macroporosity cannot alone account for the porosity increase from oil to gas window. There is an accompanying change in the volume of micro and meso porosity. Intra-organic matter
Secondary electron micrograph

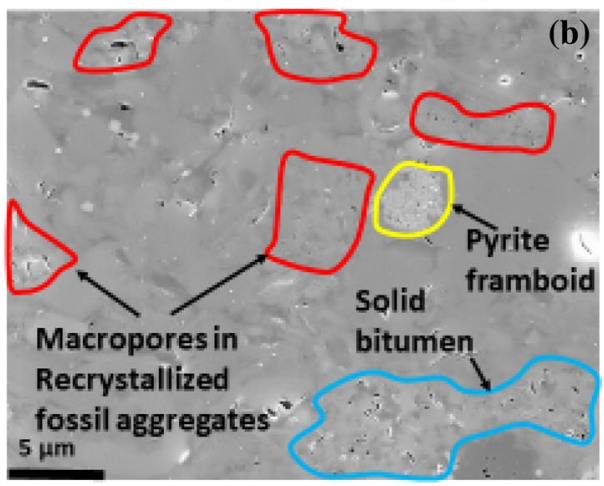

cement all indicate diagenetic transformation of the original material. b Secondary electron micrograph: Pores in recrystallized fossil aggregates occur at the interface with organic matter filling the intra-granular space

pores are a characteristic feature of gas window shales, but macroporosity is most commonly observed at the kerogenmineral interface (see Fig. 15).

Broad Ion Beam (BIB) -SEM, MICP, and gas sorption methods individually only generate partial descriptions of shale pore systems. In combination, they generate a quantitative description of the size distribution and connectivity of pores ranging in size from nanometer to micrometer $[36,84]$. Pore size and volume data have been placed into a mineralogical clay-rich, microfossil-rich and organic matter and textural framework in order to be more predictive about the pore systems of shales generally. Clay-rich domains are both micro- and meso- porous (pore diameters $<40 \mathrm{~nm}$ ) at all maturities. At temperatures below gas generation macropores are mainly $50-300 \mathrm{~nm}$ diameter. During oil generation carbonate-related macropores are traps for bitumen with porosity reduced due to bitumen retention and physicochemical compaction.

Gasification of organic matter increases porosity due to the loss of both solid phase and liquid phase organic matter. The porosity generated does not only occur within the organic matter but is physically associated with organic matter within carbonate porosity. Evolution of porosity with increasing maturity is thus linked to changes in both carbonate and organic matter domains. By quantifying the nature of pores in the various mineral and organic building blocks of shales we can consider the larger scale flow properties of shales and thus their potential either to transmit fluid (useful for a shale gas reservoir) or to retain fluid (useful for a $\mathrm{CO}_{2}$ or nuclear waste storage site). These findings are consistent with a recent study [85]. 


\section{Conclusions}

The storage of methane in shale geological reservoirs is complex due to the heterogeneous nature of shale, which contains both mineral and amorphous organic kerogen components. Adsorption of methane under simulated geological conditions presented major challenges due to the low shale methane adsorption capacities and the wide range of temperatures (300-473 K) and pressures ( $<150$ bar). Therefore, detailed validation of the accuracy and reproducibility of the experimental methods was required as a prerequisite to studying other aspects of shale gas storage.

High pressure methane sorption capacities and pore characteristics of bulk shales and isolated kerogens were investigated for immature, oil-window and gas-window samples from the lower Toarcian Posidonia formation. The equivalent maximum pore throat diameter for Posidonia shale samples were in the range $21-547 \mathrm{~nm}$ and optical microscopy did not reveal any visible porosity $>1 \mu \mathrm{m}$. However, only two samples at each maturity level have been studied. Total pore volumes obtained from MICP porosimetry and subcritical $\mathrm{CO}_{2}$ sorption volumes (195 K) of organic-rich Posidonia shales decrease through the oil-window and then increase into the gas-window. The sum of porosities measured by $\mathrm{CO}_{2}$ sorption at $195 \mathrm{~K}$ and mercury injection capillary pressure porosimetry [1.379-268.9 MPa (1093-5.6 nm)] were equal to the corresponding total pore volume $(<1093 \mathrm{~nm})$ for shales thereby giving an equation that accounts for virtually all the available porosity in this series of shales. The mercury injection at $268.9 \mathrm{MPa}$ occupies pores with constrictions larger than ca. $5.6 \mathrm{~nm}$ indicating that porosity measured by $\mathrm{CO}_{2}$ adsorption at $195 \mathrm{~K}$ is largely within pores smaller than $5.6 \mathrm{~nm}$. The $\mathrm{CO}_{2}$ sorption pore volume represented $21-66 \%$ of the total pore volume in these shales, while the meso/macropore volume from MICP was $40-79 \%$ of the total pore volume. Around $40-50 \%$ of the $\mathrm{CO}_{2}$ sorption pore volume was within the DR ultramicroporosity studies $(<0.7 \mathrm{~nm})$ in the shales studied. Oil window shales have the smallest meso/macropore fraction and the largest $\mathrm{CO}_{2}$ sorption pore volume fraction of the total porosity. It can be inferred that the adsorbed methane is predominantly in pores $<5.6 \mathrm{~nm}$ and the 'free' compressed gas is in the larger pores $(5.6-1093 \mathrm{~nm})$. The $5.6-1093 \mathrm{~nm}$ meso-macropore volume represents the major part in the Wickensen $(78 \%)$ immature and Haddessen $(63 \%)$ gas window shales, but only $41 \%$ of Harderode oil window shales. Hence the correlation allows an estimate of the contribution of the adsorbed and 'free' gas phases to the overall methane capacity.
Shale and kerogen adsorption and total organic content considerations indicate that approximately half of the $\mathrm{CH}_{4}$ sorption on dry shales occurs within the organic matter and this indicates the significance of the mineral phase, including the role of clays. Microscopic studies of the nature of pores show the importance of the intra-granular organic-mineral interface and this should be useful in understanding larger scale flow characteristics. Free compressed gas will flow much faster than sorbed gas, where desorption rates decrease with decreasing pore size.

Acknowledgements This research was supported by the GASH project funded by Bayerngas, Exxon Mobil, GdFSuez, Marathon, Repsol, Schlumberger, Total, Vermilion and Wintershall. The refurbishment of the Northern Carbon Research Laboratories was funded by the Wolfson Foundation. The authors would like to thank Dr M J Benham for discussions of high pressure adsorption methods.

\section{Compliance with ethical standards}

Conflict of interest On behalf of all authors, the corresponding author states that there is no conflict of interest.

Open Access This article is licensed under a Creative Commons Attribution 4.0 International License, which permits use, sharing, adaptation, distribution and reproduction in any medium or format, as long as you give appropriate credit to the original author(s) and the source, provide a link to the Creative Commons licence, and indicate if changes were made. The images or other third party material in this article are included in the article's Creative Commons licence, unless indicated otherwise in a credit line to the material. If material is not included in the article's Creative Commons licence and your intended use is not permitted by statutory regulation or exceeds the permitted use, you will need to obtain permission directly from the copyright holder. To view a copy of this licence, visit http://creativecommons .org/licenses/by/4.0/.

\section{References}

1. Annual Energy Outlook 2019 (2019) US Energy Information Association. https://www.eia.gov/outlooks/aeo/pdf/aeo20 19.pdf. Accessed 28 Nov 2019

2. Ambrose RJ, Hartman RC, Diaz-Campos M, Akkutlu IY, Sondergeld CH (2012) Shale gas-in-place calculations part I: new pore-scale considerations. Spe J 17(1):219-229. https://doi. org/10.2118/131772-pa

3. Montgomery SL, Jarvie DM, Bowker KA, Pollastro RM (2005) Mississippian Barnett Shale, Fort Worth basin, north-central texas: gas-shale play with multi-trillion cubic foot potential. AAPG Bull 89(2):155-175. https://doi.org/10.1306/09170404042

4. Pepper AS, Corvi PJ (1995) Simple kinetic-models of petroleum formation. 1. Oil and gas generation from Kerogen. Mar Pet Geol 12(3):291-319. https://doi.org/10.1016/0264-8172(95)98381-e

5. Ross DJK, Bustin RM (2009) The importance of shale composition and pore structure upon gas storage potential of shale gas reservoirs. Mar Pet Geol 26(6):916-927. https://doi.org/10.1016/j. marpetgeo.2008.06.004

6. Chalmers GRL, Bustin RM (2008) Lower Cretaceous gas shales in northeastern British Columbia, Part I: geological controls on 
methane sorption capacity. Bull Can Pet Geol 56(1):1-21. https ://doi.org/10.2113/gscpgbull.56.1.1

7. Weniger P, Kalkreuth W, Busch A, Krooss BM (2010) High-pressure methane and carbon dioxide sorption on coal and shale samples from the Parana Basin, Brazil. Int J Coal Geol 84(34):190-205. https://doi.org/10.1016/j.coal.2010.08.003

8. Zhang TW, Ellis GS, Ruppel SC, Milliken K, Yang RS (2012) Effect of organic-matter type and thermal maturity on methane adsorption in shale-gas systems. Org Geochem 47:120-131. https://doi. org/10.1016/j.orggeochem.2012.03.012

9. Gasparik M, Ghanizadeh A, Bertier P, Gensterblum Y, Bouw S, Krooss BM (2012) High-pressure methane sorption isotherms of black shales from the Netherlands. Energy Fuels 26(8):49955004. https://doi.org/10.1021/ef300405g

10. Lu XC, Li FC, Watson AT (1995) Adsorption measurements in devonian shales. Fuel 74(4):599-603. https://doi. org/10.1016/0016-2361(95)98364-k

11. Chareonsuppanimit $P$, Mohammad $S A$, Robinson RL, Gasem KAM (2012) High-pressure adsorption of gases on shales: measurements and modeling. Int J Coal Geol 95:34-46. https://doi. org/10.1016/j.coal.2012.02.005

12. Chalmers GRL, Bustin RM (2007) The organic matter distribution and methane capacity of the lower Cretaceous strata of northeastern British Columbia, Canada. Int J Coal Geol 70(1-3):223239. https://doi.org/10.1016/j.coal.2006.05.001

13. Chalmers GRL, Bustin RM (2008) Lower Cretaceous gas shales in northeastern British Columbia, Part II: evaluation of regional potential gas resources. Bull Can Pet Geol 56(1):22-61. https:// doi.org/10.2113/gscpgbull.56.1.22

14. Gasparik M, Bertier P, Gensterblum Y, Ghanizadeh A, Krooss BM, Littke R (2014) Geological controls on the methane storage capacity in organic-rich shales. Int J Coal Geol 123:34-51. https://doi.org/10.1016/j.coal.2013.06.010

15. Li J, Zhou SX, Gaus G, Li YJ, Ma Y, Chen KF, Zhang YH (2018) Characterization of methane adsorption on shale and isolated kerogen from the Sichuan Basin under pressure up to $60 \mathrm{MPa}$ : experimental results and geological implications. Int J Coal Geol 189:83-93. https://doi.org/10.1016/j.coal.2018.02.020

16. Chen L, Zuo L, Jiang ZX, Jiang S, Liu KY, Tang JQ, Zhang LC (2019) Mechanisms of shale gas adsorption: evidence from thermodynamics and kinetics study of methane adsorption on shale. Chem Eng J 361:559-570. https://doi.org/10.1016/j. cej.2018.11.185

17. Clarkson CR, Freeman $M$, He L, Agamalian $M$, Melnichenko $Y B$, Mastalerz M, Bustin RM, Radlinski AP, Blach TP (2012) Characterization of tight gas reservoir pore structure using USANS/ SANS and gas adsorption analysis. Fuel 95(1):371-385. https ://doi.org/10.1016/j.fuel.2011.12.010

18. Mastalerz M, He LL, Melnichenko YB, Rupp JA (2012) Porosity of coal and shale: insights from gas adsorption and SANS/ USANS techniques. Energy Fuels 26(8):5109-5120. https://doi. org/10.1021/ef300735t

19. Ruppert LF, Sakurovs R, Blach TP, He LL, Melnichenko YB, Mildner DFR, Alcantar-Lopez L (2013) A USANS/SANS study of the accessibility of pores in the Barnett Shale to methane and water. Energy Fuels 27(2):772-779. https://doi.org/10.1021/ ef301859s

20. Milliken KL, Rudnicki M, Awwiller DN, Zhang TW (2013) Organic matter-hosted pore system, Marcellus Formation (Devonian), Pennsylvania. AAPG Bull 97(2):177-200. https://doi. org/10.1306/07231212048

21. Loucks RG, Reed RM, Ruppel SC, Hammes U (2012) Spectrum of pore types and networks in mudrocks and a descriptive classification for matrix-related mudrock pores. AAPG Bull 96(6):10711098. https://doi.org/10.1306/08171111061
22. Loucks RG, Reed RM, Ruppel SC, Jarvie DM (2009) Morphology, genesis, and distribution of nanometer-scale pores in siliceous mudstones of the Mississippian Barnett Shale. J Sedim Res 79(11-12):848-861. https://doi.org/10.2110/jsr.2009.092

23. Borst RL (1982) Some effects of compaction and geological time on the pore parameters of argillaceous rocks. Sedimentology 29(2):291-298. https://doi.org/10.1111/j.1365-3091.1982.tb017 26.X

24. Yang YL, Aplin AC (1998) Influence of lithology and compaction on the pore size distribution and modelled permeability of some mudstones from the Norwegian margin. Mar Pet Geol 15(2):163-175. https://doi.org/10.1016/s0264-8172(98)00008-7

25. Cartwright JA, Dewhurst DN (1998) Layer-bound compaction faults in fine-grained sediments. Geol Soc Am Bull 110(10):12421257. https://doi.org/10.1130/0016-7606(1998)110\%3c124 2:Lbcfif\%3e2.3.Co;2

26. Gensterblum Y, Ghanizadeh A, Cuss RJ, Amann-Hildenbrand A, Krooss BM, Clarkson CR, Harrington JF, Zoback MD (2015) Gas transport and storage capacity in shale gas reservoirs - a review. Part A: transport processes. J Unconv Oil Gas Resour 12:87-122. https://doi.org/10.1016/j.juogr.2015.08.001

27. Wang Y, Liu LF, Sheng Y, Wang XM, Zheng SS, Luo ZH (2019) Investigation of supercritical methane adsorption of overmature shale in Wufeng-Longmaxi Formation, Southern Sichuan Basin, China. Energy Fuels 33(3):2078-2089. https://doi.org/10.1021/ acs.energyfuels.8b04344

28. Liu YL, Hou J (2019) Investigation on the potential relationships between geophysical properties and $\mathrm{CH}_{4}$ adsorption in a typical shale gas reservoir. Energy Fuels 33(9):8354-8362. https://doi. org/10.1021/acs.energyfuels.9b01905

29. Yang F, Xie CJ, Ning ZF, Krooss BM (2017) High-pressure methane sorption on dry and moisture-equilibrated shales. Energy Fuels 31(1):482-492. https://doi.org/10.1021/acs.energyfuels.6b029 99

30. Wang L, Yu QC (2016) The effect of moisture on the methane adsorption capacity of shales: a study case in the eastern Qaidam Basin in China. J Hydrol 542:487-505. https://doi. org/10.1016/j.jhydrol.2016.09.018

31. Li XQ, Krooss BM (2017) Influence of grain size and moisture content on the high-pressure methane sorption capacity of Kimmeridge Clay. Energy Fuels 31(11):11548-11557. https:// doi.org/10.1021/acs.energyfuels.7b01298

32. Schovsbo NH, Nielsen AT, Klitten $K$, Mathiesen A, Rasmussen $P$ (2011) Shale gas investigations in Denmark: lower palaeozoic shales on Bornholm. Geol Surv Den Greenl Bull 23:9-12

33. Bernard S, Horsfield B, Schulz HM, Wirth R, Schreiber A, Sherwood N (2012) Geochemical evolution of organic-rich shales with increasing maturity: a STXM and TEM study of the Posidonia Shale (Lower Toarcian, northern Germany). Mar Pet Geol 31(1):70-89. https://doi.org/10.1016/j.marpetgeo.2011.05.010

34. Rexer TF, Mathia EJ, Aplin AC, Thomas KM (2014) High-Pressure Methane Adsorption and Characterization of Pores in Posidonia Shales and Isolated Kerogens. Energy Fuels 28(5):2886-2901. https://doi.org/10.1021/ef402466m

35. Rexer TFT, Benham MJ, Aplin AC, Thomas KM (2013) Methane adsorption on shale under simulated geological temperature and pressure conditions. Energy Fuels 27(6):3099-3109. https ://doi.org/10.1021/ef400381v

36. Mathia EJ, Bowen L, Thomas KM, Aplin AC (2016) Evolution of porosity and pore types in organic-rich, calcareous, Lower Toarcian Posidonia Shale. Mar Pet Geol 75:117-139. https://doi. org/10.1016/j.marpetgeo.2016.04.009

37. Lemmon EW, Huber ML, McLinden MO (2010) NIST reference fluid thermodynamic and transport properties-REFPROP. NIST Standard Reference Database 23. U.S. Department of Commerce, Boulder 
38. Span R, Wagner W (1996) A new equation of state for carbon dioxide covering the fluid region from the triple-point temperature to $1100 \mathrm{~K}$ at pressures up to $800 \mathrm{MPa}$. J Phys Chem Ref Data 25(6):1509-1596. https://doi.org/10.1063/1.555991

39. Span R, Lemmon EW, Jacobsen RT, Wagner W, Yokozeki A (2000) A reference equation of state for the thermodynamic properties of nitrogen for temperatures from 63.151 to $1000 \mathrm{~K}$ and pressures to $2200 \mathrm{MPa}$. J Phys Chem Ref Data 29(6):1361-1433. https ://doi.org/10.1063/1.1349047

40. Setzmann U, Wagner W (1991) A new equation of state and tables of thermodynamic properties for methane covering the range from the melting line to $625-\mathrm{K}$ at pressures up to 1000-MPA. J Phys Chem Ref Data 20(6):1061-1155. https://doi. org/10.1063/1.555898

41. Leon C (1998) New perspectives in mercury porosimetry. Adv Colloid Interface Sci 76:341-372. https://doi.org/10.1016/s0001 -8686(98)00052-9

42. Washburn EW (1921) The dynamics of capillary flow. Phys Rev 17(3):273-283. https://doi.org/10.1103/PhysRev.17.273

43. Lapierre C, Leroueil S, Locat J (1990) Mercury intrusion and permeability of Louiseville Clay. Can Geotech J 27(6):761-773. https ://doi.org/10.1139/t90-090

44. Heling D (1970) Micro-fabrics of shales and their rearrangement by compaction. Sedimentology 15(3-4):247. https://doi. org/10.1111/j.1365-3091.1970.tb02188.x

45. Gensterblum $Y$, van Hemert $P$, Billemont $P$, Busch $A$, Charriere $D$, Li D, Krooss BM, de Weireld G, Prinz D, Wolf K (2009) European inter-laboratory comparison of high pressure $\mathrm{CO}_{2}$ sorption isotherms. I: activated carbon. Carbon 47(13):2958-2969. https:// doi.org/10.1016/j.carbon.2009.06.046

46. Nguyen HGT, Espinal L, van Zee RD, Thommes M, Toman B, Hudson MSL, Mangano E, Brandani S, Broom DP, Benham MJ, Cychosz K, Bertier P, Yang F, Krooss BM, Siegelman RL, Hakuman M, Nakai K, Ebner AD, Erden L, Ritter JA, Moran A, Talu O, Huang Y, Walton KS, Billemont P, De Weireld G (2018) A reference highpressure $\mathrm{CO}_{2}$ adsorption isotherm for ammonium ZSM-5 zeolite: results of an interlaboratory study. Adsorpt J Int Adsorpt Soc 24(6):531-539. https://doi.org/10.1007/s10450-018-9958-x

47. Gasparik M, Rexer TFT, Aplin AC, Billemont P, De Weireld G, Gensterblum Y, Henry M, Krooss BM, Liu SB, Ma XZ, Sakurovs R, Song ZG, Staib G, Thomas KM, Wang SB, Zhang TW (2014) First international inter-laboratory comparison of high-pressure $\mathrm{CH}_{4}, \mathrm{CO}_{2}$ and $\mathrm{C}_{2} \mathrm{H}_{6}$ sorption isotherms on carbonaceous shales. Int J Coal Geol 132:131-146. https://doi.org/10.1016/j.coal.2014.07.010

48. Xiao B, Wheatley PS, Zhao XB, Fletcher AJ, Fox S, Rossi AG, Megson IL, Bordiga S, Regli L, Thomas KM, Morris RE (2007) Highcapacity hydrogen and nitric oxide adsorption and storage in a metal-organic framework. J Am Chem Soc 129(5):1203-1209. https://doi.org/10.1021/ja066098k

49. Lin X, Telepeni I, Blake AJ, Dailly A, Brown CM, Simmons JM, Zoppi M, Walker GS, Thomas KM, Mays TJ, Hubberstey P, Champness NR, Schroder M (2009) High capacity hydrogen adsorption in $\mathrm{Cu}$ (II) tetracarboxylate framework materials: the role of pore size, ligand functionalization, and exposed metal sites. J Am Chem Soc 131(6):2159-2171. https://doi.org/10.1021/ja806624j

50. Furukawa H, Miller MA, Yaghi OM (2007) Independent verification of the saturation hydrogen uptake in MOF-177 and establishment of a benchmark for hydrogen adsorption in metalorganic frameworks. J Mater Chem 17(30):3197-3204. https:// doi.org/10.1039/b703608f

51. Murray LJ, Dinca M, Long JR (2009) Hydrogen storage in metalorganic frameworks. Chem Soc Rev 38(5):1294-1314. https:// doi.org/10.1039/b802256a

52. Pan HH, Ritter JA, Balbuena PB (1998) Examination of the approximations used in determining the isosteric heat of adsorption from the Clausius-Clapeyron equation. Langmuir 14(21):6323-6327. https://doi.org/10.1021/la9803373

53. Himeno S, Komatsu T, Fujita S (2005) High-pressure adsorption equilibria of methane and carbon dioxide on several activated carbons. J Chem Eng Data 50(2):369-376. https://doi. org/10.1021/je049786x

54. Rahman KA, Loh WS, Yanagi H, Chakraborty A, Saha BB, Chun WG, Ng KC (2010) Experimental adsorption isotherm of methane onto activated carbon at sub- and supercritical temperatures. J Chem Eng Data 55(11):4961-4967. https://doi.org/10.1021/ je1005328

55. Reid CR, Thomas KM (2001) Adsorption kinetics and size exclusion properties of probe molecules for the selective porosity in a carbon molecular sieve used for air separation. J Phys Chem B 105(43):10619-10629. https://doi.org/10.1021/jp0108263

56. Ruppel TC, Grein CT, Bienstock D (1974) Adsorption of methane on dry coal at elevated pressure. Fuel 53(3):152-162. https://doi. org/10.1016/0016-2361(74)90002-7

57. Li LJ, Bell JG, Tang SF, Lv XX, Wang C, Xing YL, Zhao XB, Thomas KM (2014) Gas storage and diffusion through nanocages and windows in porous metal-organic framework $\mathrm{Cu}-2(2,3,5,6-$ tetramethylbenzene-1,4-diisophthalate) $\left(\mathrm{H}_{2} \mathrm{O}\right)(2)$. Chem Mat 26(16):4679-4695. https://doi.org/10.1021/cm403697m

58. Iliin B (1923) General theory of sorption phenomena. Z Physik Chem 107:145-153

59. Swan E, Urquhart AR (1927) Adsorption equations: a review of the literature. J Phys Chem 31:251-276

60. Gurvitch LG (1915) Physico-chemical attractive force. II. J Russ Phys Chim 47(805):827

61. Rodriguez-Reinoso F, Linares-Solano A (1989) Microporous structure of activated carbons as revealed by adsorption methods. In: Thrower PA (ed) Chemistry and physics of carbon, vol 21. Marcel Dekker, New York, pp 1-146

62. Brunauer $\mathrm{S}$, Emmett $\mathrm{PH}$, Teller E (1938) Adsorption of gases in multimolecular layers. J Am Chem Soc 60(2):309-319. https:// doi.org/10.1021/ja01269a023

63. Firouzi M, Rupp EC, Liu CW, Wilcox J (2014) Molecular simulation and experimental characterization of the nanoporous structures of coal and gas shale. Int J Coal Geol 121:123-128. https://doi.org/10.1016/j.coal.2013.11.003

64. Psarras P, Holmes R, Vishal V, Wilcox J (2017) Methane and $\mathrm{CO}_{2}$ adsorption capacities of Kerogen in the Eagle Ford Shale from molecular simulation. Acc Chem Res 50(8):1818-1828. https ://doi.org/10.1021/acs.accounts.7b00003

65. Marsh H, Wynne-Jones WFK (1964) The surface properties of carbon-I the effect of activated diffusion in the determination of surface area. Carbon 1(3):269-279. https://doi. org/10.1016/0008-6223(64)90281-7

66. Sing K (2001) The use of nitrogen adsorption for the characterisation of porous materials. Colloid Surf A Physicochem Eng Asp 187:3-9. https://doi.org/10.1016/s0927-7757(01)00612-4

67. Mahajan OP (1991) $\mathrm{CO}_{2}$ surface area of coals - the 25-year paradox. Carbon 29(6):735-742. https://doi.org/10.1016/00086223(91)90010-g

68. Lamond TG, Metcalfe JEI, Waler PLJ (1965) $6 \AA$ molecular sieve properties of saran-type carbons. Carbon 3(1):59-63. https:// doi.org/10.1016/0008-6223(65)90028-X

69. Dubinin MM, Radushkevich LV (1947) Equation of the characteristic curve of activated charcoa. Proc Acad Sci USSR 55:331-333

70. Marsh H (1987) Adsorption methods to study microporosity in coals and carbons-a critique. Carbon 25(1):49-58. https://doi. org/10.1016/0008-6223(87)90039-x

71. Cazorla-Amoros D, Alcaniz-Monge J, de la Casa-Lillo MA, LinaresSolano A (1998) $\mathrm{CO}_{2}$ as an adsorptive to characterize carbon 
molecular sieves and activated carbons. Langmuir 14(16):45894596. https://doi.org/10.1021/la980198p

72. Garrido J, Linares -Solano A, Martin-Martinez JM, Molina-Sabio $M$, Rodriguez-Reinoso F, Torregrosa $\mathrm{R}$ (1987) Use of $\mathrm{N}_{2}$ vs $\mathrm{CO}_{2}$ in the Characterization of activated carbons. Langmuir 3(1):76-81. https://doi.org/10.1021/la00073a013

73. Sing KSW, Everett DH, Haul RAW, Moscou L, Pierotti RA, Rouquerol J, Siemieniewska T (1985) Reporting physisorption data for gas solid systems with special reference to the determination of surface-area and porosity (recommendations 1984). Pure Appl Chem 57(4):603-619. https://doi.org/10.1351/pac19 8557040603

74. Cole JH, Everett DH, Marshall CT, Paniego AR, Powl JC, Rodriguez-Reinoso $F$ (1974) Thermodynamics of high temperature adsorption of some permanent gases by porous carbons. J Chem Soc Faraday Trans I 70:2154-2169. https://doi. org/10.1039/f19747002154

75. Myers AL, Monson PA (2002) Adsorption in porous materials at high pressure: theory and experiment. Langmuir 18(26):1026110273. https://doi.org/10.1021/la026399h

76. Ji LM, Zhang TW, Milliken KL, Qu JL, Zhang XL (2012) Experimental investigation of main controls to methane adsorption in clay-rich rocks. Appl Geochem 27(12):2533-2545. https://doi. org/10.1016/j.apgeochem.2012.08.027

77. Tang X, Ripepi N, Stadie NP, Yu LJ (2017) Thermodynamic analysis of high pressure methane adsorption in Longmaxi shale. Fuel 193:411-418. https://doi.org/10.1016/j.fuel.2016.12.047

78. Zhou SW, Wang HY, Zhang PY, Guo W (2019) Investigation of the isosteric heat of adsorption for supercritical methane on shale under high pressure. Adsorpt Sci Technol 37(7-8):590-606. https ://doi.org/10.1177/0263617419866986

79. Clarkson CR, Bustin RM (1996) Variation in micropore capacity and size distribution with composition in bituminous coal of the Western Canadian Sedimentary Basin-implications for coalbed methane potential. Fuel 75(13):1483-1498. https://doi. org/10.1016/0016-2361(96)00142-1

80. Clarkson CR, Bustin RM, Levy JH (1997) Application of the mono/ multilayer and adsorption potential theories to coal methane adsorption isotherms at elevated temperature and pressure. Carbon 35(12):1689-1705. https://doi.org/10.1016/s0008 -6223(97)00124-3

81. Gurdal G, Yalcin MN (2001) Pore volume and surface area of the Carboniferous coals from the Zonguldak basin (NW Turkey) and their variations with rank and maceral composition. Int J Coal Geol 48(1-2):133-144. https://doi.org/10.1016/s0166 $-5162(01) 00051-9$

82. Laxminarayana C, Crosdale PJ (1999) Role of coal type and rank on methane sorption characteristics of Bowen Basin, Australia coals. Int J Coal Geol 40(4):309-325. https://doi.org/10.1016/ s0166-5162(99)00005-1

83. Cai YD, Liu DM, Pan ZJ, Yao YB, Li JQ, Qiu YK (2013) Pore structure and its impact on $\mathrm{CH} 4$ adsorption capacity and flow capability of bituminous and subbituminous coals from Northeast China. Fuel 103:258-268. https://doi.org/10.1016/j.fuel.2012.06.055

84. Mathia EJ, Rexer TFT, Thomas KM, Bowen L, Aplin AC (2019) Influence of clay, calcareous microfossils, and organic matter on the nature and diagenetic evolution of pore systems in mudstones. J Geophys Res Solid Earth 124(1):149-174. https://doi. org/10.1029/2018jb015941

85. Aljamaan H, Ross CM, Kovscek AR (2017) Multiscale imaging of gas storage in shales. Spe J 22(6):1760-1777

Publisher's Note Springer Nature remains neutral with regard to jurisdictional claims in published maps and institutional affiliations. 